\title{
Applications of Gold Nanoparticles in Non-Optical Biosensors
}

\author{
Pengfei Jiang ${ }^{1} \mathbb{D}$, Yulin Wang ${ }^{1}$, Lan Zhao ${ }^{1}$, Chenyang Ji ${ }^{1}$, Dongchu Chen ${ }^{2}$ and Libo Nie ${ }^{1, *}$ \\ 1 Hunan Key Laboratory of Biomedical Nanomaterials and Devices, Hunan University of Technology, \\ Zhuzhou 412007, China; m16077700001@stu.hut.edu.cn (P.J.); m18077700009@stu.hut.edu.cn (Y.W.); \\ m18077700015@stu.hut.edu.cn (L.Z.); 16420200115@stu.hut.edu.cn (C.J.) \\ 2 School of Material Science and Energy Engineering, Foshan University, Foshan 528000, China; \\ chendc@fosu.edu.cn \\ * Correspondence: nielibo@hut.edu.cn; Fax: +86-73122182107
}

Received: 29 October 2018; Accepted: 22 November 2018; Published: 26 November 2018

\begin{abstract}
Due to their unique properties, such as good biocompatibility, excellent conductivity, effective catalysis, high density, and high surface-to-volume ratio, gold nanoparticles (AuNPs) are widely used in the field of bioassay. Mainly, AuNPs used in optical biosensors have been described in some reviews. In this review, we highlight recent advances in AuNP-based non-optical bioassays, including piezoelectric biosensor, electrochemical biosensor, and inductively coupled plasma mass spectrometry (ICP-MS) bio-detection. Some representative examples are presented to illustrate the effect of AuNPs in non-optical bioassay and the mechanisms of AuNPs in improving detection performances are described. Finally, the review summarizes the future prospects of AuNPs in non-optical biosensors.
\end{abstract}

Keywords: gold nanoparticles; biosensor; piezoelectric; electrochemical; ICP-MS

\section{Introduction}

Nanoparticles are defined as particles with sizes between 1 and $100 \mathrm{~nm}$. Due to their physical and chemical properties such as high specific surface area, electrical performance, magnetism, optical and catalytic property, nanoparticles have received great attention in many research fields [1,2]. Especially, AuNPs have excellent properties such as good biocompatibility, excellent conductivity, effective catalysis, high density, and high surface-to-volume ratio, which are widely used in the field of bioassay [3-9].

As one of the most stable metal nanoparticles, AuNPs play an important role in the field of biosensors. AuNPs can be easily modified with biomolecules such as DNAs and proteins by thiol and amine via Au-S or Au-N bonds without destroying the activity of biomolecules. In optical biosensors, AuNPs are widely used to improve the detection sensitivity of fluorescence, chemiluminescence, surface plasmon resonance (SPR), surface-enhanced Raman scattering (SERS) method, and other optical detection [10-13]. The AuNPs are usually used as fluorescence quenchers, catalysts, immobilization platforms, colorimetric nanoparticles, as well as SPR and SERS enhancers in optical biosensors. It shows that the sensitivities of optical biosensors are effectively improved based on the signal amplification of AuNPs. However, the optical detections usually require expensive instruments such as fluorescent spectrometers, SPR/SERS instruments, which increases the cost of bioassay.

In non-optical biosensors, AuNPs are mainly used in piezoelectric biosensors, electrochemical biosensors and ICP-MS biosensors. In piezoelectric biosensors, AuNPs usually act as labels which make use of their high density to increase the mass change and improve the sensitivity of detection $[14,15]$. In electrochemical biosensors, AuNPs are often used as immobilization platform, electrocatalyst or 
electron migration enhancer which exhibit advantages in improving the sensitivity, selectivity and stability of detection [16-18]. In recent years, AuNPs have also been reported in biological detection based on ICP-MS technology [19-22]. Similar to optical biosensors, the performances of non-optical biosensors are effectively improved based on the signal amplification of AuNPs. Although the instruments of non-optical detection are simple, the detection procedures are not as automatic and rapid as those of the optical biosensors, which are not widely used in clinic application.

In this review, we focus on the applications of AuNPs in non-optical bioassay strategies of piezoelectric biosensors, electrochemical biosensors and ICP-MS detections. The effects of AuNPs in these detection methods are described. Finally, we summarize the future prospects of AuNPs in non-optical biosensors.

\section{Piezoelectric Biosensors}

The most common type of piezoelectric biosensor is quartz crystal microbalance (QCM), which is a sensitive technique based on the piezoelectric effect [23]. When a mechanical force is exerted on the quartz crystal, the crystal generates an electric potential in the direction of the applied force. Oppositely, when an electric field is applied to the crystal, the crystal generates mechanical vibrations. When a certain substance is adsorbed on the surface of quartz crystal, the resonance frequency of the crystal will shift from its basic frequency. Therefore, the mass change on the surface of quartz crystal can be detected by the frequency shift according to piezoelectric effect. QCM biosensors possess the advantages of high sensitivity at a nanogram level, label-free and real-time monitoring, which is widely used in the detection of genes, proteins, cells, microorganisms, toxins and so on [24-44].

Because of their large specific surface area, AuNPs are often immobilized on the surface of the quartz crystal in order to connect more biomolecules in QCM biosensors. Jiang's team reported that AuNPs were immobilized on the surface of a gold electrode to increase the number of capture probes and hybridize more target DNAs. It suggested that the sensitivity of this method is three times more than that without AuNP immobilization [45]. Moreover, they deposited AuNPs on the surface of platinum coated QCM (Pt-QCM) to provide more binding sites for HS-DNA, and the maximum immobilization amount of HS-DNA on (Au)Pt-QCM was about three-fold more than that on bare Pt-QCM [46]. In addition, to immobilize more AuNPs on the surface of the crystal, they developed a novel method that a large amount of AuNPs were adsorbed on the surface of polystyrene microspheres which were immobilized on the surface of Au electrode, with a low detection limit of $10^{-12} \mathrm{M}$ for DNA analysis [47].

Obviously, AuNPs have a significant signal amplification effect in QCM biosensors due to their heavier masses than biomolecules. Owing to their high density, AuNPs have potential as labels to increase the mass change on the quartz surface [48-50]. Jiang et al. used AuNPs of $50 \mathrm{~nm}$ as the mass enhancer to amplify the frequency signal of QCM, which reached a low detection limit of $10^{-14} \mathrm{M}$ for target DNA [51]. Furthermore, they improved the detection limit to $10^{-16} \mathrm{M}$ by modifying AuNPs on the surface of gold electrode and labeling AuNPs with probe DNA simultaneously [52,53]. Premaratne et al. carried out a similar research and obtained an ultralow detection limit of $28 \mathrm{fM}$ for target oligonucleotide [54]. To further increase the frequency shift, Chen et al. exploited a QCM-DNA sensor with a layer-by-layer AuNPs structure by DNA hybridization, which achieved an ultralow detection limit of 2 plaque forming units (PFU)/mL for dengue virus (DENV) [55]. Kim et al. found that the introduction of AuNP modified antibodies increased the signal by $53.4 \%$ compared with that without AuNPs modification [56]. Tang and co-workers proposed a novel displacement-type QCM immunosensor based on AuNPs, which lead to a significant frequency shift, and a detection limit as low as $0.6 \mathrm{pg} \cdot \mathrm{mL}^{-1}$ for brevetoxin B (PbTx-2) (Figure 1) [57]. 


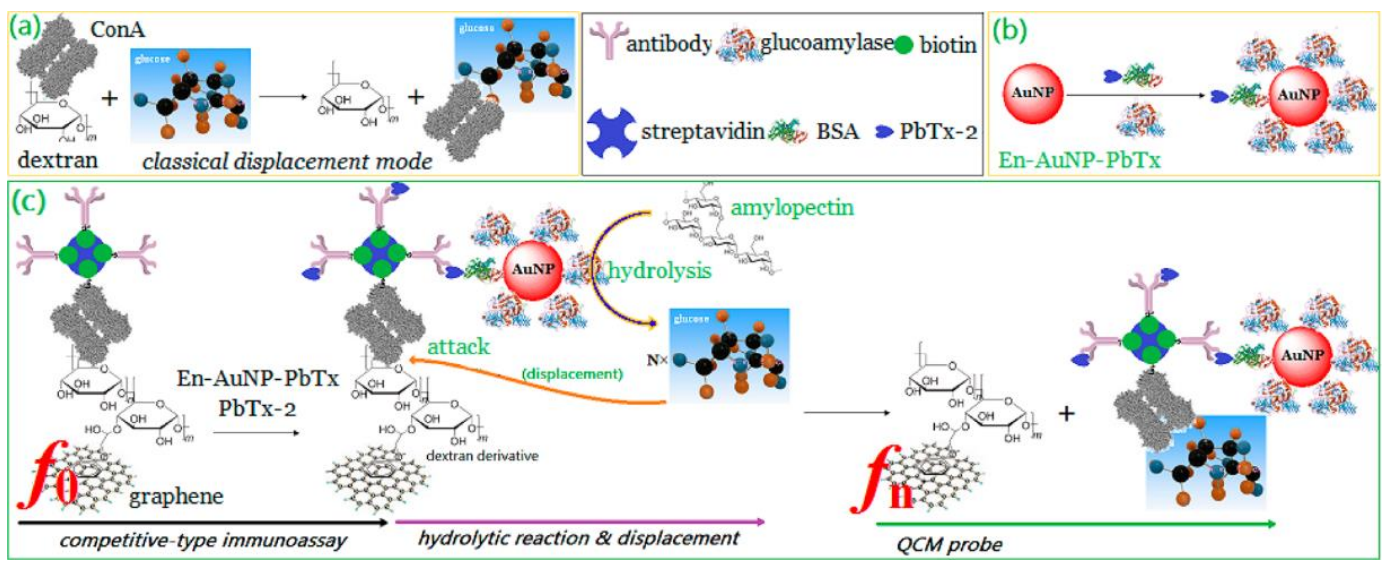

Figure 1. (a) Conventional displacement-type assay protocol based on the dextran-concanavalin A (ConA)-glucose system, (b) schematic illustration of gold nanoparticle heavily functionalized with glucoamylase and PbTx-2 BSA, and (c) measurement principle of the displacement-type QCM immunosensor. Reproduced with permission from [57]. American Chemical Society, 2013.

The technique of gold label silver stain (GLSS) is also an excellent choice to enhance the mass change in QCM biosensor. In the presence of reducing agents such as hydroquinone quinol (HQ), AuNPs catalyze the reduction of silver ions to form silver element which deposits on the surface of AuNPs to obtain Au@Ag core-shell structure, which highly increases the mass change and improve the detection sensitivity. Shan et al. constructed a QCM cell sensor based on the classical GLSS signal amplification method, and the limit of detection (LOD) for acute leukemia cells was 1160 cells $\cdot \mathrm{mL}^{-1}[58]$.

Another effective way to improve the sensitivity of QCM biosensors is to combine AuNPs with biological amplifying technologies. Sun et al. developed a method with multi-cycle signal amplification based on AuNPs and hybridized chain reaction (HCR), which the large number of AuNPs were assembled on the HCR products for signal amplification, and the detection limit of the target DNA was as low as $0.7 \mathrm{fM}[59]$.

\section{Electrochemical Biosensors}

Electrochemical biosensors show the advantages of high sensitivity, low-cost, amenable miniaturization and operating convenience. AuNPs play an important role in improving the sensitivity and specificity of electrochemical biosensors, such as modifying the sensing surface to enhance conductivity, increasing the immobilization of biomolecules and catalyzing the electrochemical reactions. In addition, AuNPs are also used as the electrochemical indicators.

\subsection{AuNPs as the Electrochemical Indicators}

AuNPs can be used as electrochemical indicators based on the redox reaction between $\mathrm{Au}^{0}$ and $\mathrm{Au}^{3+}$ [60]. In electrochemical biosensors, the ways to detect AuNPs signal mainly include: (i) direct detection of the oxidation signal of AuNPs without treatment [61]. (ii) AuNPs are electro-oxidized to gold ions in hydrochloric acid ( $\mathrm{HCl}$ ) solution [62-67]. (iii) AuNPs are dissolved in $\mathrm{HBr} / \mathrm{Br}_{2}$ acidic solution $[68,69]$.

Kerman et al. reported an electrochemical sensor for DNA detection by the direct oxidation of AuNPs without acid treatment, which provided a detection limit of $2.17 \mathrm{pM}$ for target DNA [70]. Although it is simple to detect AuNPs directly, most of AuNPs cannot be detected due to their distances away from electrodes. Therefore, AuNPs are usually oxidized to gold ions in most electrochemical detections. Trau et al. reported a fast and sensitive electrochemical detection in which the AuNPs were electrochemically oxidized to $\mathrm{Au}^{3+}$ in $\mathrm{HCl}$ solution at first, and then the reduction of gold ions was detected which obtained a detection limit as low as 1 colony-forming 
units (CFU) for Mycobacterium tuberculosis (Mtb) DNA [71]. Ilkhani et al. designed an electrochemical sandwich immunosensor in which cathodic preconcentration and anode stripping of gold were performed after AuNPs were dissolved in $\mathrm{HCl}$ solution. The detection limit of this method was $50 \mathrm{pg} \cdot \mathrm{mL}^{-1}$ [72]. Preconcentration of gold ions on the surface of electrodes can increase the recovery rate of AuNPs and enhance the electrochemical signals. Qin et al. reported a new method by cathodic preconcentration of gold ions. Unlike traditional AuNP electrochemical measurements, a cathodic potential ( $0 \mathrm{~V}$ here) was firstly applied on the electrode in air, and then the dissolution of AuNPs and cathode preconcentration simultaneously performed in microliter-droplet aqueous $\mathrm{HBr} / \mathrm{Br}_{2}$. $\mathrm{This}$ scheme presented high signal recovery efficiency of AuNPs, and the detection limit was as low as $0.3 \mathrm{fg} \cdot \mathrm{mL}^{-1}$ for human immunoglobulin $\mathrm{G}(\mathrm{hIgG})$ and $0.1 \mathrm{fg} \cdot \mathrm{mL}^{-1}$ for the human prostate-specific antigen (hPSA) (Figure 2) [73].

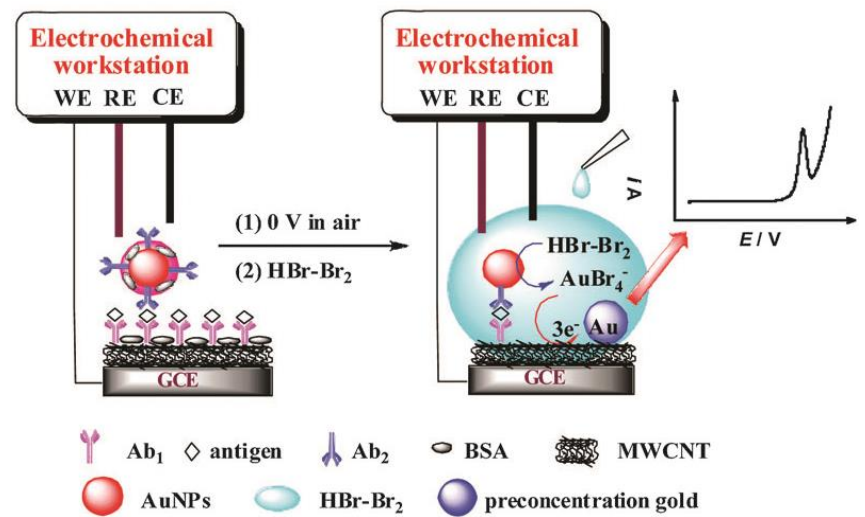

Figure 2. Illustration of key electrochemical steps of the metal-labeled amperometric immunoassay signal amplification protocol. Reproduced with permission from [73]. Royal Society of Chemistry, 2015.

The corrosive solutions such as $\mathrm{HBr} / \mathrm{Br}_{2}$ and $\mathrm{HCl}$ used in dissolving AuNPs are harmful to the ecological environment and human health. Therefore, green reagents are needed to replace acidic electrolytes for AuNP electrooxidation. Recently, $\mathrm{NaNO}_{3} / \mathrm{NaCl}$ mixture was first proposed by Baldrich et al. as a potential alternative. The results showed that $\mathrm{NaNO}_{3} / \mathrm{NaCl}$ mixture exhibited better electrooxidation performance than other oxidized salts, but the reduction peak is much lower than that of the $\mathrm{HCl}$ solution. It's also suggested that $\mathrm{NaNO}_{3} / \mathrm{NaCl}$ provided nanoimmunoconjugate quantization in all the concentration range. Therefore, $\mathrm{NaNO}_{3} / \mathrm{NaCl}$ can be used to substitute $\mathrm{HCl}$, providing a more environmentally friendly method for electrochemical measurement of AuNPs (Figure 3) [74].

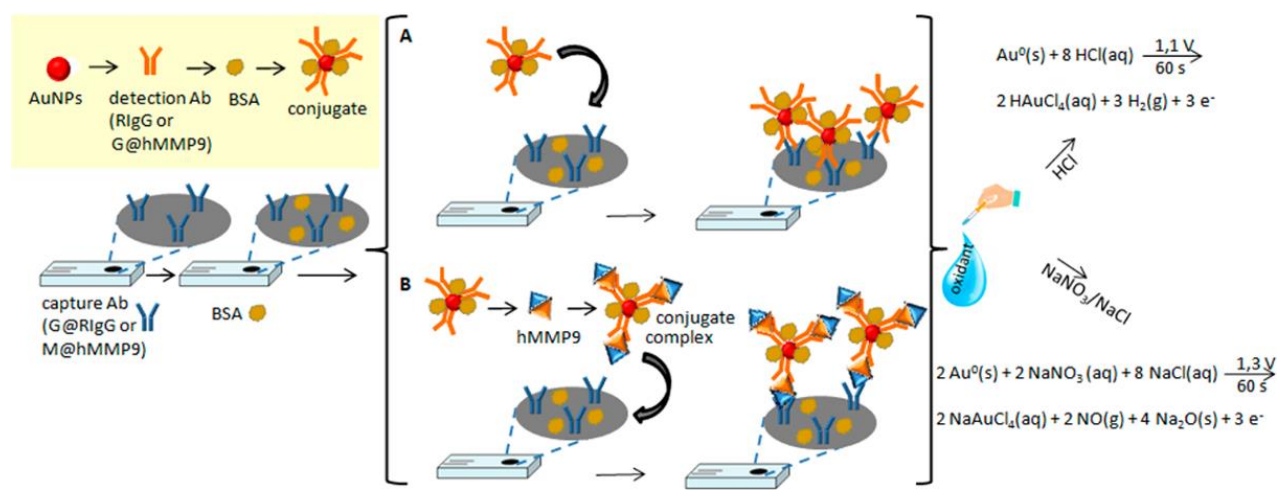

Figure 3. Scheme of the preparation of the two immunosensors used and their analytical working principle. (A) model system and (B) immunosensor for hMMP9 detection. Reproduced with permission from [74]. American Chemical Society, 2018. 


\subsection{AuNPs as the Electron Migration Enhancers}

In electrochemical biosensors, the electrochemical redox reaction generates electron exchange on the electrode, which is relative to the concentration of the analytes. However, the direct electrochemical detection is often difficult to achieve because of the weak electrical conductivity of biomolecules which blocks the transfer of electrons to the electrode. In order to enhance the conductivity, AuNPs are usually immobilized on the surface of the electrode, which not only enhances the electron transfer rate in the electrochemical process, but also enlarges the sensing area to increase the immobilized amount of the recognition unit, thereby achieving the improvement of sensitivity.

As early as 1996, Natan's group had demonstrated the direct electron transfer of AuNPs between proteins and electrodes [75]. Since that, much research using AuNPs as the electron migration enhancer has been published [76-80]. Electrodeposition is a common method to immobilize AuNPs on the surface of electrodes. Zhao et al. electrochemically deposited AuNPs on the surface of glassy carbon electrode (GCE), and a wide linear range from $0.5 \mathrm{pg} \cdot \mathrm{mL}^{-1}$ to $100 \mathrm{ng} \cdot \mathrm{mL}^{-1}$ and the ultralow detection limit of $145.69 \mathrm{fg} \cdot \mathrm{mL}^{-1}$ was achieved for prostate-specific antigen (PSA) detection [81]. Bao et al. also used AuNPs deposition modified GCE to detect DNA methylation and DNA methyltransferase [82]. Another way to modify AuNPs on the surface of electrodes is the direct immobilization of AuNPs. Jarocka et al. immobilized AuNPs on the surface of gold electrode as the electron migration enhancer, achieving a LOD of $2.2 \mathrm{pg} \cdot \mathrm{mL}^{-1}$ for target protein [83]. The size of AuNPs has influence on the performance of the biosensor, affecting mainly linearity of the output signal and reproducibility of assays. To immobilize more AuNPs on the electrode surface, a three-dimensional structure of AuNPs was developed by Wang's group. They designed a layer-by-layer assembly of AuNPs on the surface of electrode by para-Sulfonatocalix[4] arene $\left(\mathrm{pSC}_{4}\right)$ modified AuNPs and 1,6-hexanediamine (HMD) conjugation through host-guest recognition. With enhanced electron migration and large specific surface area of AuNPs, this structure showed a detection limit of $0.5 \mathrm{ng} \cdot \mathrm{mL}^{-1}$ for human epidermal growth factor receptor $2\left(\mathrm{ErbB}_{2}\right)$ (Figure 4$)$ [84].

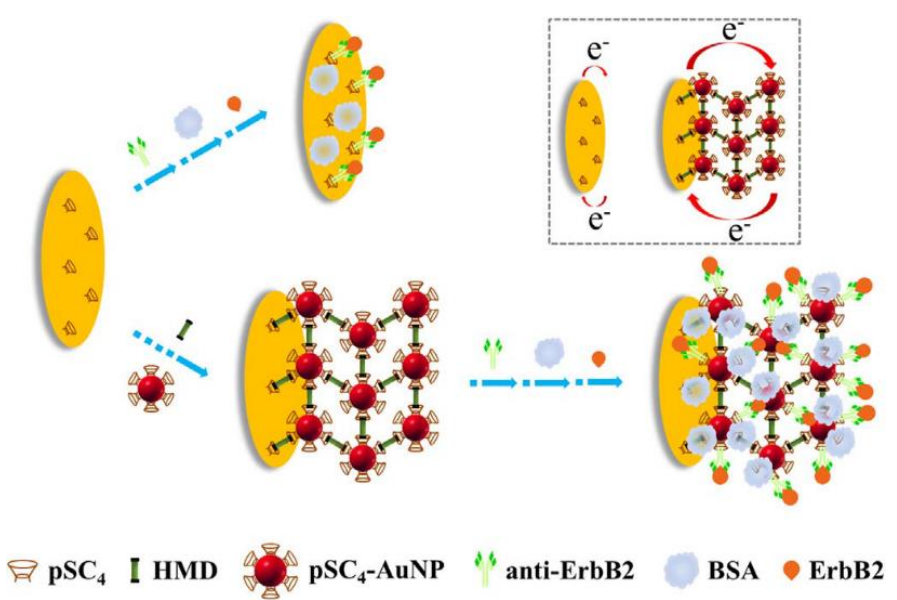

Figure 4. Schematic of $\mathrm{pSC}_{4}$ monolayer and $\mathrm{pSC}_{4}$-gold nanoparticles (AuNPs) layer-by-layer signal amplification on the electrode surface. Reproduced with permission from [84]. Elsevier, 2018.

To enhance the conductivity furthermore, AuNPs are also combined with other high conductive materials such as graphene, carbon nanotubes and dendrimers in electrochemical biosensor. Wang et al. developed an electrochemical DNA sensor in which the chitosan-graphene sheet and polyaniline were modified on the surface of GCE to increase the effective surface area of the electrode to deposit more AuNPs. The detection limit of this method was as low as $2.11 \mathrm{pM}$ [85]. Gao et al. reported an electrochemical immunosensor based on AuNPs and Nile blue A (NB) hybridized electrochemically reduced graphene oxide (NB-ERGO). In this study, NB-graphene oxide (NB-GO) and $\mathrm{HAuCl}_{4}$ were simultaneously reduced to synthesize AuNPs/NB-ERGO on the surface of the electrode, which 
provided a large surface area for antibody attachment, achieving a detection limit of $1 \mathrm{pg} \cdot \mathrm{mL}^{-1}$ for carcinoembryonic antigen (CEA) [86]. Furthermore, to enhance the specific surface area of electrode, Shuai et al. proposed an ultrasensitive electrochemical biosensor by combining tungsten oxide-graphene $\left(\mathrm{WO}_{3}-\mathrm{Gr}\right)$ composites with AuNPs on the electrode to provide more binding sites for the probes, obtaining a detection limit of $0.05 \mathrm{fM}$ for microRNA [87]. Nanocarbon materials are often used in electrochemical biosensors due to their good conductivity. Bai et al. attached the electrode by single-walled carbon nanotube modified AuNPs to improve the conductivity of the electrode and provide more binding sites for biomolecules, receiving a detection limit of $8 \mathrm{pM}$ for platelet-derived growth factor (PDGF) and $11 \mathrm{pM}$ for thrombin respectively [88]. Liu et al. produced a composite of AuNPs coated with graphitized mesoporous carbon nanoparticles for the detection of PSA. This composite increased the electron transfer rate and the immobilizing number of aptamers on the surface of electrode, resulting in a limit of detection less than $0.25 \mathrm{ng} \cdot \mathrm{mL}^{-1}$ and a linear detection range from 0.25 to $200 \mathrm{ng} \cdot \mathrm{mL}^{-1}$ [89]. In addition, dendrimer-encapsulated AuNPs are also developed to enhance the signal of electrochemical biosensors, which possess the advantages of high density of active groups, excellent structural homogeneity, good biocompatibility and conductivity. Jeong et al. reported the poly(amidoamine) dendrimer encapsulated AuNPs (PAMAM-AuNPs) for CEA detection, which not only increased the immobilized amount of the antibody, but also accelerated the electron transfer process, resulting in a linear dynamic range of $10.0 \mathrm{pg} \cdot \mathrm{mL}^{-1}$ to $50.0 \mathrm{ng} \cdot \mathrm{mL}^{-1}$ and a detection limit of $4.4 \mathrm{pg} \cdot \mathrm{mL}^{-1}$ [90]. Zhang et al. also exploited a highly sensitive electrochemical immunosensor based on PAMAM-AuNPs with a detection limit of $50 \mathrm{CFU} \cdot \mathrm{mL}^{-1}$ for Escherichia coli (E. coli) [91].

In addition, AuNPs are also used in molecularly imprinted electrochemical biosensors by increasing the surface area of the recognition unit and improving the conductivity of the molecularly imprinted polymer (MIP) film [92]. Yang and co-workers developed a novel molecularly imprinted electrochemical sensor for cholesterol $(\mathrm{CHO})$ detection based on bioinspired Au microflowers. In this study, the bioinspired Au microflowers were formed on the surface of the electrode by wrapping AuNPs on the bioinspired polydopamine (PDA) film through electropolymerization, followed by the coating of MIP. The linear response range of this strategy was between $10^{-18}$ and $10^{-13} \mathrm{M}$, with an ultralow detection limit of $3.3 \times 10^{-19} \mathrm{M}$, which is more sensitive than the traditional $\mathrm{CHO}$ detection method (Figure 5) [93].

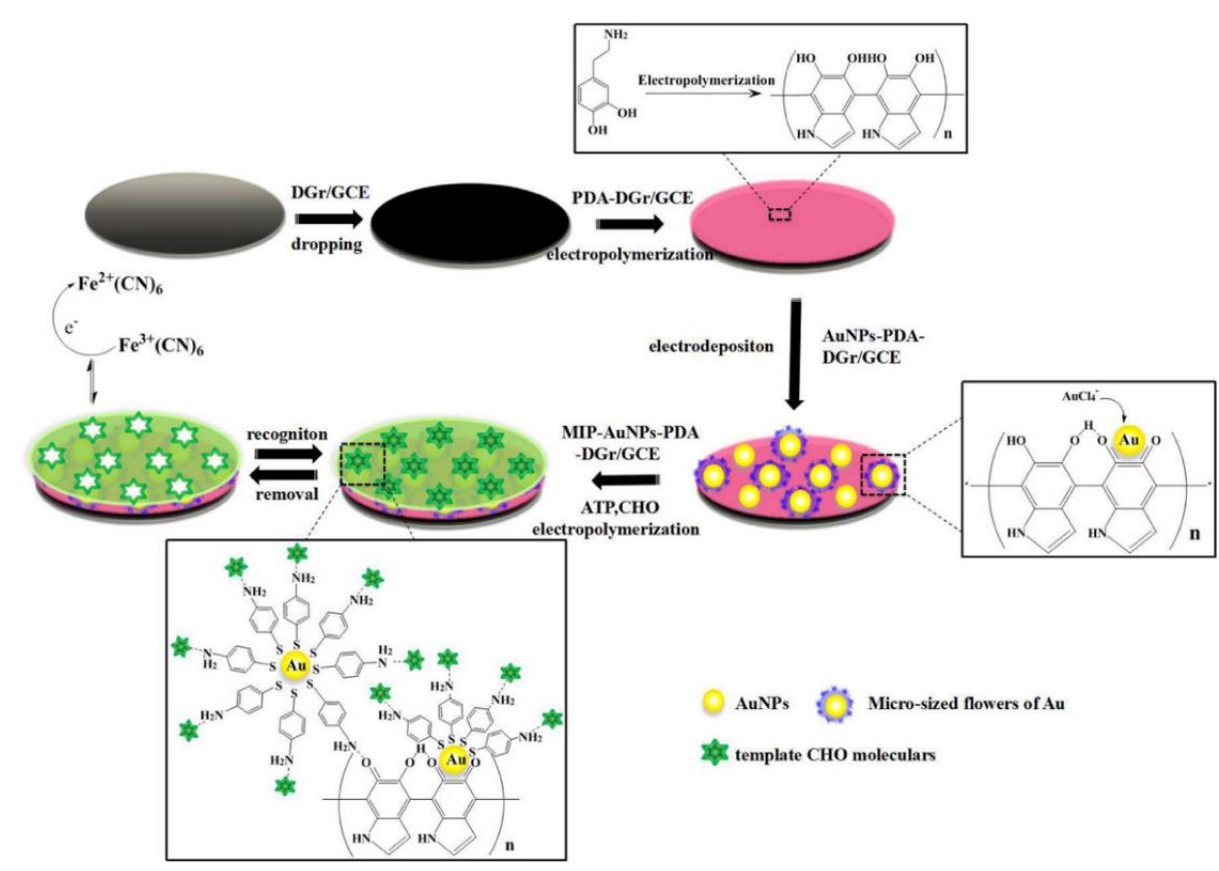

Figure 5. The preparation process of MIP-AuNPs-PDA-DGr/GCE. Reproduced with permission from [93]. Elsevier, 2017. 
The regeneration of biosensor is able to simplify operation, reduce cost and save time, which is favourite in the detection process. Sun et al. developed an ultrasensitive electrochemical biosensor for the detection of human liver hepatocellular carcinoma (HepG2) cells. After measurement, an electrochemical reductive desorption method was performed to break gold thiol bond and desorb the components on the surface of AuNPs/GCE, which retained 90\% of the original sensitivity [94].

\subsection{AuNPs as the Immobilization Platform}

For electrochemical biosensors, the number of electroactive molecules is a key factor to the detection sensitivity, which is usually improved by increasing the amount of electrochemical signal molecules through various amplifying strategies. Because of the advantages of large specific surface area and easy conjugation with biomolecules by Au-S bond, AuNPs are usually used as the immobilization platform to connect a large number of biomolecules, resulting in the conjugation of a great deal of electrochemical signal molecules [95-104].

Wang and co-workers developed an electrochemical DNA sensor based on the amplification of AuNPs. In this method, a large number of the methylene blue (MB) labeled DNA probes were immobilized on the surface of AuNPs. Attribute to the large specific surface area of AuNPs, the electrochemical signals of $\mathrm{MB}$ were effectively amplified, resulting in a detection range of $10^{-13}$ to $10^{-8} \mathrm{M}$ and a detection limit as low as $50 \mathrm{fM}$ [105]. Shu et al. modified 6-ferrocenyl hexanethiol (Fc) and aptamers on the surface of AuNPs simultaneously that the amount of the former was much more than that of the latter. After the biorecognition of aptamers and CEA, the amplified electrechemical signal of Fc significantly improved the detection sensitivity [106]. Hasanzadeh et al. used AuNPs to support histidine (nano-Au-Hist), which showed a perfect discriminatory power for the Brucella-specific probe hybridization [107]. Wang et al. reported AuNPs as the platform to immobilize DNAs for the detection of ampicillin [108]. In addition, AuNPs often combined with other nanomaterials to further improve the performance of the biosensors. Chen et al. reported that the AuNPs were grown on the surface of the octahedral $\mathrm{Cu}_{2} \mathrm{O}$ nanocrystals to increase the surface area and immobilize recognition components and electroactive substances, which presented a detection limit as low as $23 \mathrm{fM}$ for thrombin (TB) [109].

Combining AuNPs with signal amplifying technologies is a common way to increase the detection sensitivity of electrochemical biosensors. Zhu's group designed an electrochemical detection strategy based on spherical nucleic acids AuNPs triggered mimic-hybridization chain reaction (mimic-HCR). The AuNP carried DNA probes initiated the mimic-HCR which the double-stranded structure bound a large amount of $\left[\mathrm{Ru}\left(\mathrm{NH}_{3}\right)_{6}\right]^{3+}$ to amplify the electrochemical signal [110]. Recently, Bo et al. developed a triple-signal amplification method for the determination of miRNA. In this protocol, AuNPs were connected together to form the bridge DNA-AuNPs nanocomposites, which was used to absorb a large number of electrochemical indicator $\left[\mathrm{Ru}\left(\mathrm{NH}_{3}\right)_{6}\right]^{3+}$. This strategy achieved a wide detection linear range of $10^{-17}$ to $10^{-11} \mathrm{M}$, with limit of detection as low as 6.8 aM (Figure 6) [111]. Yu et al. developed AuNPs hot-spots self-assemble structure by catalytic hairpin assembly (CHA) reaction to improve the absorption amount of $\left[\mathrm{Ru}\left(\mathrm{NH}_{3}\right)_{6}\right]^{3+}$, obtaining a detection limit as low as 25.1 aM for miRNA-141 [112]. It suggests that AuNPs combined with bio-amplification technologies such as bio-barcode HCR, CHA lead to a detection limit as low as aM level, which is of great prospect to enhance the sensitivity of electrochemical biosensors.

In addition, Wang et al. reported a multiple electrochemical detection method for quantitative analysis of miRNAs. In this work, gold nanoparticle-coated magnetic microbeads (AuNP-MMBs) were used as the carrier to connect two hairpin probes. At the same time, the electrochemical indicators $\mathrm{MB}$ and Fc modified diblock oligonucleotides (ODNs) were immobilized on the surface of AuNPs as the signal output. Two target miRNAs were detected simultaneously with detection limits as low as $0.2 \mathrm{fM}$ and $0.12 \mathrm{fM}$ for miRNA-182 and miRNA-381 respectively (Figure 7) [113]. 


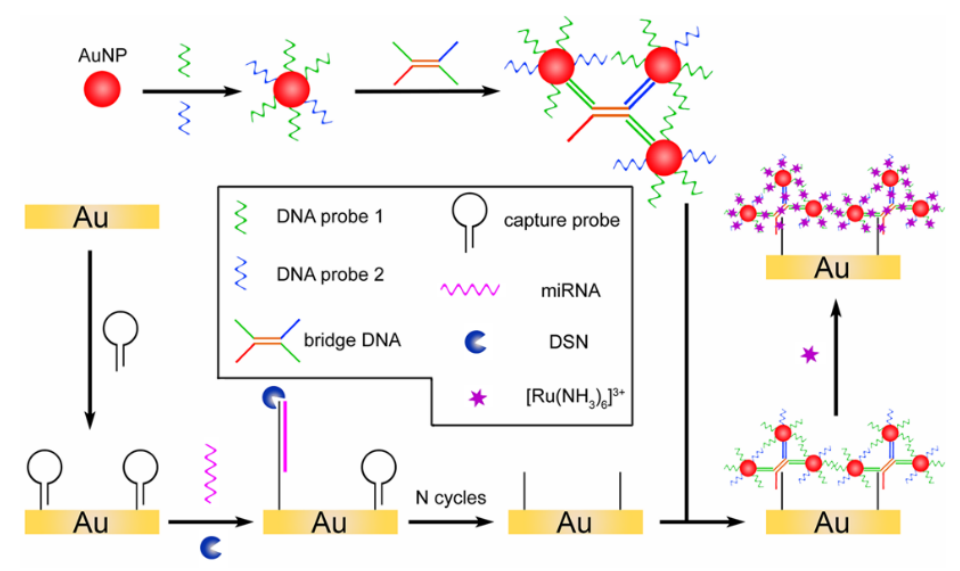

Figure 6. Illustration of the electrochemical approach for triple amplified detection of miRNA. Reproduced with permission from [111]. American Chemical Society, 2018.

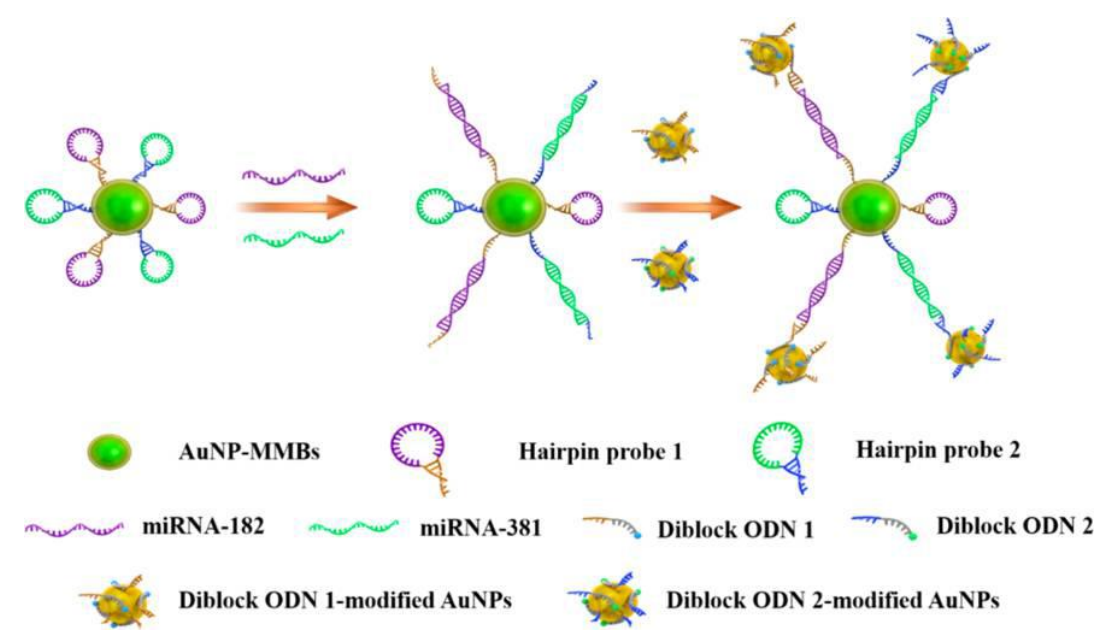

Figure 7. Schematic showing the simultaneous electrochemical detection of miRNA-182 and miRNA-381 via the conjugates of AuNP-MMBs and diblock ODN-modified AuNPs. Reproduced with permission from [113]. American Chemical Society, 2017.

\subsection{AuNPs as the Catalyst}

Bulk gold is chemically inert, while AuNPs exhibit extraordinary catalytic capability [114-117]. Studies show that the catalytic activity of AuNPs arises from their quantum scale, high surface-to-volume ratio and interface-dominated property, which is able to reduce the overpotential of electrochemical reactions and accelerate the chemical reaction, leading to the improvement of detection sensitivity. Typically, AuNPs are used to catalyze redox reactions such as nicotinamide adenine dinucleotide (NADH), hydrogen peroxide $\left(\mathrm{H}_{2} \mathrm{O}_{2}\right)$, 4-nitrophenol, o-phenylenediamine (o-PD), catechol and nitrite [118-120].

Raj et al. described the electrocatalytic oxidation effect of AuNPs on NADH. The self-assembly of AuNPs on a thiol-terminated three-dimensional silicate network modified on the surface of the electrode catalyzed the oxidation of $\mathrm{NADH}$, reducing the overpotential by $915 \mathrm{mV}$ without any electron transfer mediator [121]. Li et al. prepared a sandwich immunosensor for the analysis of alpha fetoprotein (AFP). In this study, AuNPs functionalized magnetic multi-walled carbon nanotubes (MWCNTs- $\mathrm{Fe}_{3} \mathrm{O}_{4}$ ) were utilized to adsorb lead ions and antibodies, which exhibited good electrocatalytic activity for the reduction of $\mathrm{H}_{2} \mathrm{O}_{2}$. Under optimal experimental conditions, the detection limit reached $3.33 \mathrm{fg} \cdot \mathrm{mL}^{-1}$ for AFP [122]. Cao et al. structured an AuNP network to catalyze the redox of $\mathrm{H}_{2} \mathrm{O}_{2}$ and $\mathrm{HQ}$, with a detection limit of $0.32 \mathrm{pM}$ for lysozyme [123]. 
To improve the electrochemical signals, considerable research efforts have been devoted to the application of GLSS in electrochemical biosensors [124-131]. Because of the amplification of GLSS, the electrochemical signal of silver is highly improved, which leads to the enhancement of detection sensitivity. Lai et al. constructed an electrochemical immunoassay strategy based on GLSS for the detection of human and mouse IgG [132]. The amount of AuNPs is one of the keys to enhance the effect of GLSS. Recently, Zhang et al. used polypyrrole microsphere (PPyMS) to immobilize more AuNPs for the amplification of silver label signal. A low detection limit of $0.1 \mathrm{ng} \cdot \mathrm{L}^{-1}$ and a wide linear range of $0.25 \mathrm{ng} \cdot \mathrm{L}^{-1}$ to $50 \cdot \mathrm{L}^{-1}$ was obtained for microcystin-LR (MC-LR) detection [133].

Combining AuNPs with other nanomaterials is also an effective way to improve the performance of electrochemical biosensors. Yang et al. used AuNPs functionalized nitrogen-doped graphene quantum dots (Au@N-GQDs) to enhance conductivity and synthesized the echinoidea-shaped nanocomposites $\left(\mathrm{Au} @ \mathrm{Ag}-\mathrm{Cu}_{2} \mathrm{O}\right)$ which composed of $\mathrm{Au} @ \mathrm{Ag}$ core-shell nanoparticles and disordered cuprous oxide to label antibodies. Taking advantages of the conductivity and catalysis of AuNPs, an ultralow detection limit of $0.003 \mathrm{pg} \cdot \mathrm{mL}^{-1}$ for PSA was achieved [134]. Studies show that the size of AuNPs affects the catalysis of silver deposition, and relatively high deposition currents of silver can be obtained using small AuNPs. Duangkaew et al. developed a triple signal amplification strategy based on small-sized gold nanoparticles for the electrochemical detection of PSA. In this method, the size of AuNPs was increased by forming an Au shell on the surface of the small AuNP tags, and then the spiky AuNPs were grown on the surface of Au shell, with the benefit of enhancing the catalysis of silver. Compared to the traditional GLSS process, this triple signal amplification strategy magnified the electrical signal by 260 times (Figure 8) [135].

The electrochemical biosensors based on AuNPs are summarized in Table 1.

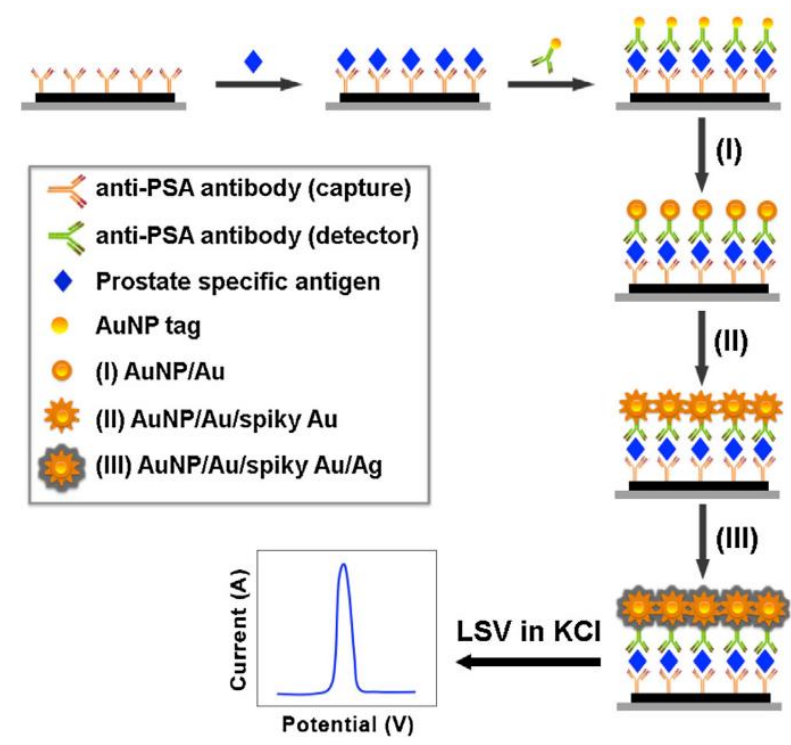

Figure 8. Schematic representation of triple signal amplification strategy based on AuNPs serving as labeling tags. Sandwich immunoreaction of PSA was used as an immunosensing model. Linear sweep voltametric analysis was performed to detect deposited silver. Reproduced with permission from [135]. Elsevier, 2017. 
Table 1. Electrochemical biosensors based on AuNPs.

\begin{tabular}{|c|c|c|c|c|}
\hline Analytes $^{a}$ & Electrode Modification $^{b}$ & Functions of AuNPs & Detection Limits & Ref. \\
\hline$M t b$ DNA & SPCE/SA & Electrochemical indicators & $1 \mathrm{CFU}$ & [71] \\
\hline EGFR & GCE & Electrochemical indicators & $50 \mathrm{pg} / \mathrm{mL}$ & [72] \\
\hline hIgG, hPSA & GCE/MWCNT/AB & Electrochemical indicators & $0.3 \mathrm{fg} / \mathrm{mL}, 0.1 \mathrm{fg} / \mathrm{mL}$ & [73] \\
\hline hMMP9 & SPCE /AB & Electrochemical indicators & $0.06 \mathrm{ng} / \mathrm{mL}$ & [74] \\
\hline PSA & GCE/AuNPs/AB & Electron migration enhancers & $145.69 \mathrm{fg} / \mathrm{mL}$ & [81] \\
\hline M.SssI MTase & GCE/AuNPs/CP & Electron migration enhancers & $0.04 \mathrm{U} / \mathrm{mL}$ & [82] \\
\hline $\mathrm{ErbB}_{2}$ & $\mathrm{GE} / \mathrm{pSC}_{4} / \mathrm{HMD} / \mathrm{AuNPs}$ & Electron migration enhancers & $0.5 \mathrm{ng} / \mathrm{mL}$ & {$[84]$} \\
\hline ssDNA & GCE/CS-GS/PANI/AuNPs/CP & Electron migration enhancers & $2.11 \mathrm{pM}$ & [85] \\
\hline CEA & GCE/NB-ERGO/AuNPs/AB & Electron migration enhancers & $1 \mathrm{pg} / \mathrm{mL}$ & [86] \\
\hline MicroRNA & $\mathrm{GCE} / \mathrm{WO}_{3}-\mathrm{Gr} / \mathrm{AuNPs} / \mathrm{CP}$ & Electron migration enhancers & $0.05 \mathrm{fM}$ & [87] \\
\hline PDGF, TB & GCE/SWCNTs@AuNPs/AB & Electron migration enhancers & $8 \mathrm{pM}, 11 \mathrm{pM}$ & [88] \\
\hline PSA & PGE/GMCs@AuNPs/AB & Electron migration enhancers & $0.25 \mathrm{ng} / \mathrm{mL}$ & [89] \\
\hline CEA & GE/Cys/AuNPs@PAMAM/Th/AB & Electron migration enhancers & $4.4 \mathrm{pg} / \mathrm{mL}$ & [90] \\
\hline ssDNA & $\mathrm{GE} / \mathrm{CP}$ & Immobilization platform & $50 \mathrm{fM}$ & [105] \\
\hline Ampicillin & GCE/AuNPs/Aptamer & Immobilization platform & $0.3 \mathrm{pM}$ & [108] \\
\hline TB & GCE/AuNPs/Aptamer & Immobilization platform & $23 \mathrm{fM}$ & [109] \\
\hline MiRNA & $\mathrm{GE} / \mathrm{CP}$ & Immobilization platform & $6.8 \mathrm{aM}$ & [111] \\
\hline MiRNA-141 & $\mathrm{GE} / \mathrm{CP}$ & Immobilization platform & $25.1 \mathrm{aM}$ & [112] \\
\hline MiRNA-182, MiRNA-381 & MGE & Immobilization platform & $0.2 \mathrm{fM}, 0.12 \mathrm{fM}$ & [113] \\
\hline AFP & GCE/AuNPs/AB & Catalyst & $3.33 \mathrm{fg} / \mathrm{mL}$ & [122] \\
\hline Lysozyme & $\mathrm{GE} / \mathrm{CP}$ & Catalyst & $0.32 \mathrm{pM}$ & [123] \\
\hline Microcystin-LR & GCE/CNT/PEG & Catalyst & $0.1 \mathrm{ng} / \mathrm{L}$ & [133] \\
\hline PSA & GCE/Au@N-GQDs/AB & Catalyst & $0.003 \mathrm{pg} / \mathrm{mL}$ & [134] \\
\hline PSA & $\mathrm{SPCE} / \mathrm{CNT} / \mathrm{AB}$ & Catalyst & $1.2 \mathrm{pg} / \mathrm{mL}$ & [135] \\
\hline
\end{tabular}

a Mtb DNA: Mycobacterium tuberculosis DNA; EGFR: epidermal growth factor receptor; hIgG: human immunoglobulin G; hPSA: human prostate-specific antigen; hMMP9: human matrix metallopeptidase-9; PSA: prostate-specific antigen; M.SssI MTase: methyltransferase; ErbB 2 : human epidermal growth factor receptor 2; CEA: carcinoembryonic antigen; PDGF: platelet-derived growth factor; TB: thrombin; AFP: alpha fetoprotein. ${ }^{\mathrm{b}}$ SPCE: screen printed carbon electrode; SA: streptavidin; GCE: glassy carbon electrode; MWCNT: multiwalled carbon nanotube; AB: antibody; GE: gold electrode; $\mathrm{PSC}_{4}$ : para-Sulfonatocalix[4]arene; HMD: 1,6-hexanediamine; CS-GS: chitosan-graphene sheets; PANI: polyaniline; CP: capture probe; NB-ERGO: Nile blue A (NB) hybridized electrochemically reduced graphene oxide; $\mathrm{WO}_{3}$ : tungsten oxide; SWCNTs: single-walled carbon nanotubes; PGE: pyrolytic graphite electrode; GMCs: graphitized mesoporous carbon nanoparticles; Cys: cysteamine; PAMAM: poly(amidoamine) dendrimer; Th: thionine; MGE: magnetic gold electrode; CNT: Carbon nanotubes; PEG: polyethylene glycol; Au@N-GQDs: AuNPs functionalized nitrogen-doped graphene quantum dots. 


\section{ICP-MS Biosensor}

Inductively coupled plasma mass spectrometry (ICP-MS) combines the high-temperature ionization characteristics of inductively coupled plasma with the sensitive and fast scanning of mass spectrometers, which is a high sensitive technique for element, isotope and morphological analysis [136]. The technology offers extremely low detection limit and an extremely wide dynamic linear range with a working range more than 9 orders of magnitude, and owns the advantages of simple spectral lines, low interference, high analytical precision, rapid analysis and high specificity, which is widely used in environmental protection, biology, medicine, metallurgy, nuclear material analysis and other fields [137-143]. In the past few years, the strategies combining ICP-MS technology with metal nanoparticle labels were developed to achieve ultra-high sensitivity analysis in biomolecular analysis [144-152].

AuNPs are composed of plenty of gold atoms, which generate a huge number of Au ions by dissolution, digestion and plasma. Using AuNPs as the labels, the ultra-high sensitive detection of biomolecules is able to achieve by ICP-MS technology. He et al. developed an ICP-MS biosensor based on AuNP labels for HIV-1 p24 antigen detection. In this study, diluted $\mathrm{HNO}_{3}$ was used to dissociate AuNPs from the immunoassay complex, with a detection limit of $1.49 \mathrm{pg} \cdot \mathrm{mL}^{-1}$ by ICP-MS measurement (Figure 9) [153]. Similar methods were developed in cell and immune assay [154].

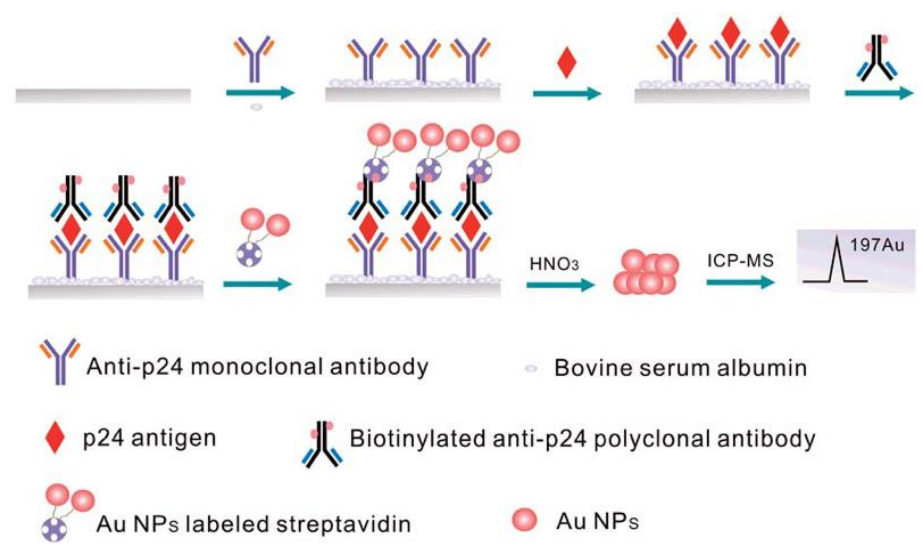

Figure 9. Schematic diagram of the sensitive assay with the BA system and Au NPs based immunoassay for p24 antigen determination by ICP-MS. Reproduced with permission from [153]. Royal Society of Chemistry, 2014.

To improve the signal of ICP-MS measurement, the amplification methods have been developed to increase the amount of labeled AuNPs. Yang et al. reported a layer-by-layer assembly method of AuNPs to amplify the ICP-MS signals for the detection of cancer cells. The detection limit of human hepatocellular carcinoma SMMC-7721 cells was as low as 100 cells $\mathrm{mL}^{-1}$ (Figure 10) [155]. Li et al. developed an ICP-MS ultrasensitive immunoassay based on AuNPs and tyramine signal amplification (TSA), with a detection limit of $1.85 \mathrm{pg} \cdot \mathrm{mL}^{-1}$ for AFP [156]. He et al. reported a new method based on rolling circle amplification (RCA) and ICP-MS detection, which provided an ultralow detection limit of $0.1 \mathrm{fM}$ and a good specificity [157]. Zhang et al. reported an AuNPs labelling and HCR amplification strategy for HepG2 cells detection by ICP-MS, with detection limit as low as 15 cells and a linear range of 40-8000 cells [158]. Li et al. reported a triple signal amplification strategy based on AuNPs, which combined RCA, nicking displacement and bio-bar-code techniques to perform ultra-sensitive detection of target DNA by ICP-MS. This strategy provided a detection limit as low as $3.2 \times 10^{-17} \mathrm{M}$ for hepatitis B virus (HBV) DNA [159]. Liu et al. reported a novel strategy based on capillary electrophoresis and inductively coupled plasma mass spectrometry (CE-ICP-MS). The results shown that more than $2000 \mathrm{Au}$ atoms were attached to each albumin with a detection limit as low as $0.1 \mathrm{aM}$ and a wide linear range of 4 orders of magnitude [160]. 


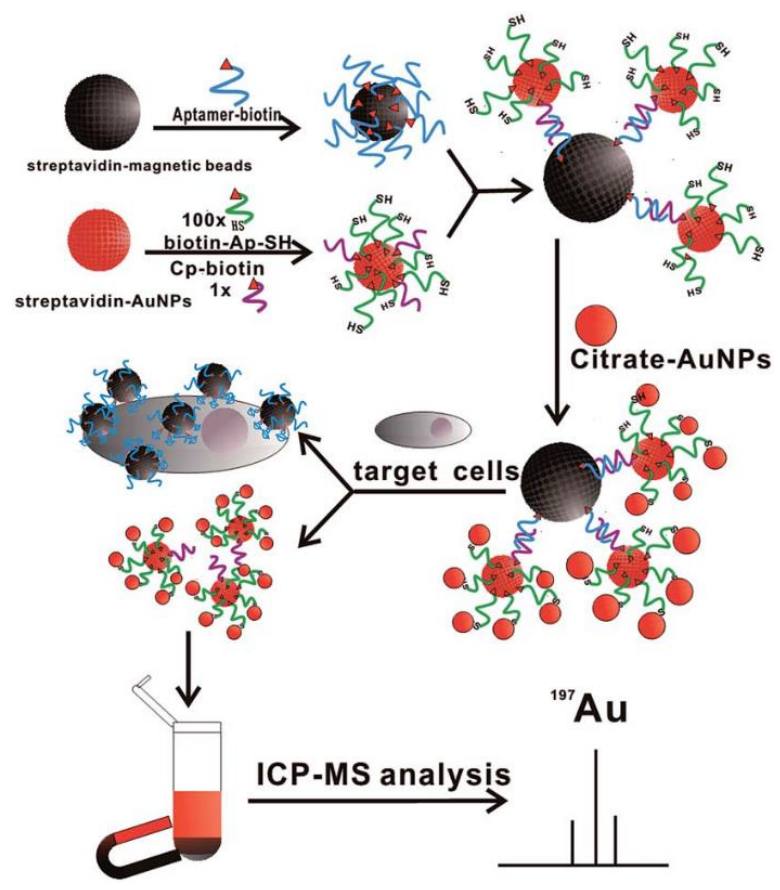

Figure 10. Schematic illustration of the experimental principle for counting cancer cells based on ICP-MS detection and a MB-based AuNP aptamer labelling technique. Reproduced with permission from [155]. Royal Society of Chemistry, 2016.

Conventional ICP-MS is usually used in analyzing the concentrations and compositions of the elements. However, single-particle mode ICP-MS (sp-ICP-MS) is able to perform multiple information analysis on the structure, shape, particle size, and agglomeration of nanoparticles, which extends the application of ICP-MS technology in bioassay [161-170]. For the first time, Allabashi et al. evaluated the possibility of direct determination of AuNPs in colloid solutions by ICP-MS, without previous digestion/dissolution. The results showed no significant difference compared to the same AuNPs by acidic digestion [171]. Liu et al. reported that ICP-MS was able to measure AuNPs with the sizes from 10 to $70 \mathrm{~nm}$ under high sensitive mode, and the size of AuNPs could be further extended to $200 \mathrm{~nm}$ in less sensitive mode [172]. In sp-ICP-MS detection, the frequency of the pulse signal is a function of the concentration of AuNP colloids and the recorded peak distribution of signal intensity is a function of size distribution. It can be used in the detection of biomolecules. Han et al. reported a DNA detection method based on AuNPs and sp-ICP-MS. In this method, the hybridization of DNA targets with DNA probes immobilized on the surface of the AuNPs resulted in the formation of dimers, trimers, or even large aggregates of AuNPs. This polymeric network aggregation led to decreased concentrations of the whole AuNP population as well as increased individual sizes. These changes were detected by sp-ICP-MS quantitatively, and thus the amount of DNA was obtained. The quantitative detection of AuNPs aggregates was performed directly and yielded a good linear relationship, with a LOD as low as $1 \mathrm{pM}$ [173]. Therefore, the sp-ICP-MS is a powerful tool for nanoparticle detection, which is environmentally friendly, and needn't use toxic reagents such as $\mathrm{HCl}$ and nitric acid to digest AuNPs.

\section{Conclusions}

Nanotechnology promotes the development of many fields such as bioassay and biorecognition [174-187]. Nanomaterials play a crucial role in enhancing the performance of biosensors. In non-optical bioassay, AuNPs are widely used to improve the detection sensitivity due to their good physical and chemical properties. Taking advantage of their heavy mass, AuNPs are utilized to increase the mass change and improve the frequency shift in piezoelectric biosensor. In electrochemical biosensor, AuNPs are used as an electrochemical indicator, electron migration enhancer and catalyst 
based on their excellent conductivity and effective catalysis. In addition, the gold element in AuNPs can be detected by ICP-MS technology. Because of their high specific surface area, AuNPs are often used as the immobilization platform to immobilize more biomolecules and enhance the detection sensitivity. Combining AuNPs with other various signal amplifying methods such as RCA, HCR, bio-barcode and layer-by-layer assembly, the sensitivities of biosensors are highly improved to achieve detection limits as low as attomole or below. Although AuNPs perform excellently in improving the sensitivity of non-optical biosensors, there are still challenges to be faced. The potential of AuNPs in non-optical bioassay should be further explored to design new bioassay strategies to achieve multiplexed analysis of biomolecules. The combination of AuNPs with novel signal amplification methods should be further investigated to enhance the sensitivity of non-optical bioassay. To develop the practicable biosensors based on AuNPs, the operation convenience, detection time, and analysis cost have to be considered. It is possible that the non-optical biosensors with good performance should be successfully applied in the field of biomedicine.

Author Contributions: P.J. did the writing and literature research for the paper. Y.W., L.Z. and C.J. contributed partial literature study and discussion. D.C. contributed the review and editing. L.N. guided and supervised the work.

Funding: This work was funded by Research and Innovative Experiment Program for College Students in Hunan Province, 201711535035, Open Fund of Guangdong Provincial Characteristic Key Discipline of Material Science, CNXY2017009, the Key Project of Department of Education of Guangdong Province, 2016GCZX008 and the Project of Engineering Research Center of Foshan, 20172010018.

Conflicts of Interest: The authors declare no conflict of interest. We declare that we do not have any commercial or associative interest that represents a conflict of interest in connection with the work submitted.

\section{References}

1. Dubertret, B.; Calame, M.; Libchaber, A.J. Single-mismatch detection using gold-quenched fluorescent oligonucleotides. Nat. Biotechnol. 2001, 19, 365-370. [CrossRef] [PubMed]

2. Imahori, H.; Fukuzumi, S. Porphyrin monolayer-modified gold clusters as photoactive materials. Adv. Mater. 2001, 13, 1197-1199. [CrossRef]

3. Gole, A.; Dash, C.; Ramakrishnan, V.; Sainkar, S.R.; Mandale, A.B.; Rao, M.; Sastry, M. Pepsin-gold colloid conjugates: Preparation, characterization, and enzymatic activity. Langmuir 2001, 17, 1674-1679. [CrossRef]

4. Liu, J.X.; Bao, N.; Luo, X.; Ding, S.N. Nonenzymatic amperometric aptamer cytosensor for ultrasensitive detection of circulating tumor cells and dynamic evaluation of cell surface N-Glycan expression. ACS Omega 2018, 3, 8595-8604. [CrossRef]

5. Raj, C.R.; Jena, B.K. Efficient electrocatalytic oxidation of NADH at gold nanoparticles self-assembled on three-dimensional sol-gel network. Chem. Commun. 2005, 0, 2005-2007. [CrossRef] [PubMed]

6. Brust, M.; Bethell, D.; Kiely, C.J.; Schiffrin, D.J. Self-assembled gold nanoparticle thin films with nonmetallic optical and electronic properties. Langmuir 1998, 14, 5425-5429. [CrossRef]

7. Halperin, W.P. Quantum size effects in metal particles. Rev. Mod. Phys. 1986, 58, 533-606. [CrossRef]

8. Ball, P.; Garwin, L. Science at the atomic scale. Nature 1992, 355, 761-766. [CrossRef]

9. Li, Y.; Schluesener, H.J.; Xu, S. Gold nanoparticle-based biosensors. Gold Bull. 2010, 43, 29-41. [CrossRef]

10. Lyon, L.A.; Musick, M.D.; Natan, M.J. Colloidal Au-enhanced surface plasmon resonance immunosensing. Anal. Chem. 1998, 70, 5177-5183. [CrossRef] [PubMed]

11. Zengin, A.; Tamer, U.; Caykara, T. Extremely sensitive sandwich assay of kanamycin using surface-enhanced Raman scattering of 2-mercaptobenzothiazole labeled gold@silver nanoparticles. Anal. Chim. Acta 2014, 817, 33-41. [CrossRef] [PubMed]

12. Zhang, Z.F.; Cui, H.; Lai, C.Z.; Liu, L.J. Gold nanoparticle-catalyzed luminol chemiluminescence and its analytical applications. Anal. Chem. 2005, 77, 3324-3329. [CrossRef] [PubMed]

13. Mayilo, S.; Kloster, M.A.; Wunderlich, M.; Lutich, A.; Klar, T.A.; Nichtl, A.; Kürzinger, K.; Stefani, F.D.; Feldmann, J. Long-range fluorescence quenching by gold nanoparticles in a sandwich immunoassay for cardiac troponin T. Nano Lett. 2009, 9, 4558-4563. [CrossRef] [PubMed]

14. Lin, L.; Zhao, H.Q.; Li, J.R.; Tang, J.A.; Duan, M.X.; Jiang, L. Study on colloidal Au-enhanced DNA sensing by quartz crystal microbalance. Biochem. Biophys. Res. Commun. 2000, 274, 817-820. [CrossRef] [PubMed] 
15. Zhou, X.C.; O'Shea, S.J.; Li, S.F.Y. Amplified microgravimetric gene sensor using Au nanoparticle modified oligonucleotides. Chem. Commun. 2000, 0, 953-954. [CrossRef]

16. Andreescu, S.; Luck, L.A. Studies of the binding and signaling of surface-immobilized periplasmic glucose receptors on gold nanoparticles: A glucose biosensor application. Anal. Biochem. 2008, 375, 282-290. [CrossRef] [PubMed]

17. Bharathi, S.; Nogami, M. A glucose biosensor based on electrodeposited biocomposites of gold nanoparticles and glucose oxidase enzyme. Analyst 2001, 126, 1919-1922. [CrossRef] [PubMed]

18. Xu, Q.; Mao, C.; Liu, N.N.; Zhu, J.J.; Sheng, J. Direct electrochemistry of horseradish peroxidase based on biocompatible carboxymethyl chitosan-gold nanoparticle nanocomposite. Biosens. Bioelectron. 2006, 22, 768-773. [CrossRef] [PubMed]

19. Kowalczyk, A.; Wagner, B.; Karbarz, M.; Nowicka, A.M. A dual DNA biosensor based on two redox couples with a hydrogel sensing platform functionalized with carboxyl groups and gold nanoparticles. Sens. Actuators B Chem. 2015, 208, 220-227. [CrossRef]

20. Matczuk, M.; Aleksenko, S.S.; Matysik, F.M.; Jarosz, M.; Timerbaev, A.R. Comparison of detection techniques for capillary electrophoresis analysis of gold nanoparticles. Electrophoresis 2015, 36, 1158-1163. [CrossRef] [PubMed]

21. Zhang, Y.; Chen, B.; He, M.; Yang, B.; Zhang, J.; Hu, B. Immunomagnetic separation combined with inductively coupled plasma mass spectrometry for the detection of tumor cells using gold nanoparticle labeling. Anal. Chem. 2014, 86, 8082-8089. [CrossRef] [PubMed]

22. Hu, S.; Zhang, S.; Hu, Z.; Xing, Z.; Zhang, X. Detection of multiple proteins on one spot by laser ablation inductively coupled plasma mass spectrometry and application to immuno-microarray with element-tagged antibodies. Anal. Chem. 2007, 79, 923-929. [CrossRef] [PubMed]

23. Curie, J.; Curie, P. Development by pressure of polar electricity in hemihedral crystals with inclined faces. Bull. Soc. Min. Fr. 1880, 3, 90.

24. Wang, L.; Wei, Q.; Wu, C.; Hu, Z.; Ji, J.; Wang, P. The Escherichia coli O157: H7 DNA detection on a gold nanoparticle-enhanced piezoelectric biosensor. Chin. Sci. Bull. 2008, 53, 1175-1184. [CrossRef]

25. Zhao, Y.; Wang, H.; Tang, W.; Hu, S.; Li, N.; Liu, F. An in situ assembly of a DNA-streptavidin dendrimer nanostructure: A new amplified quartz crystal microbalance platform for nucleic acid sensing. Chem. Commun. 2015, 51, 10660-10663. [CrossRef] [PubMed]

26. Fonseca, R.A.; Ramos-Jesus, J.; Kubota, L.T.; Dutra, R.F. A nanostructured piezoelectric immunosensor for detection of human cardiac troponin T. Sensors 2011, 11, 10785-10797. [CrossRef] [PubMed]

27. Akter, R.; Rhee, C.K.; Rahman, M.A. A highly sensitive quartz crystal microbalance immunosensor based on magnetic bead-supported bienzymes catalyzed mass enhancement strategy. Biosens. Bioelectron. 2015, 66, 539-546. [CrossRef] [PubMed]

28. Deng, X.; Chen, M.; Fu, Q.; Smeets, N.M.; Xu, F.; Zhang, Z.; Filipe, C.D.M.; Hoare, T. A highly sensitive immunosorbent assay based on biotinylated graphene oxide and the quartz crystal microbalance. ACS Appl. Mater. Interfaces 2016, 8, 1893-1902. [CrossRef] [PubMed]

29. Zhou, Y.; Xie, Q. Hyaluronic acid-coated magnetic nanoparticles-based selective collection and detection of leukemia cells with quartz crystal microbalance. Sens. Actuators B Chem. 2016, 223, 9-14. [CrossRef]

30. Zhang, S.; Bai, H.; Luo, J.; Yang, P.; Cai, J. A recyclable chitosan-based QCM biosensor for sensitive and selective detection of breast cancer cells in real time. Analyst 2014, 139, 6259-6265. [CrossRef] [PubMed]

31. Cai, J.; Yao, C.; Xia, J.; Wang, J.; Chen, M.; Huang, J.; Chang, K.; Liu, C.; Pan, H.; Fu, W. Rapid parallelized and quantitative analysis of five pathogenic bacteria by ITS hybridization using QCM biosensor. Sens. Actuators B Chem. 2011, 155, 500-504. [CrossRef]

32. Haddada, M.B.; Salmain, M.; Boujday, S. Gold colloid-nanostructured surfaces for enhanced piezoelectric immunosensing of staphylococcal enterotoxin A. Sens. Actuators B Chem. 2018, 255, 1604-1613. [CrossRef]

33. Chen, Y.S.; Hung, Y.C.; Chen, K.; Huang, G.S. Detection of gold nanoparticles using an immunoglobulincoated piezoelectric sensor. Nanotechnology 2008, 19, 495502. [CrossRef] [PubMed]

34. Turner, N.W.; Bloxham, M.; Piletsky, S.A.; Whitcombe, M.J.; Chianella, I. The use of a quartz crystal microbalance as an analytical tool to monitor particle/surface and particle/particle interactions under dry ambient and pressurized conditions: A study using common inhaler components. Analyst 2017, 142, 229-236. [CrossRef] [PubMed] 
35. Compagnone, D.; Fusella, G.C.; Del Carlo, M.; Pittia, P.; Martinelli, E.; Tortora, L.; Paolesse, R.; Di Natale, C. Gold nanoparticles-peptide based gas sensor arrays for the detection of foodaromas. Biosens. Bioelectron. 2013, 42, 618-625. [CrossRef] [PubMed]

36. Ali, S.B.; Ghatak, B.; Debabhuti, N.; Sharma, P.; Ghosh, A.; Tudu, B.; Bhattacharya, N.; Bandyopadhyay, R. Detection of $\beta$-caryophyllene in mango using a quartz crystal microbalance sensor. Sens. Actuators B Chem. 2018, 255, 3064-3073. [CrossRef]

37. Eren, T.; Atar, N.; Yola, M.L.; Karimi-Maleh, H. A sensitive molecularly imprinted polymer based quartz crystal microbalance nanosensor for selective determination of lovastatin in red yeast rice. Food Chem. 2015, 185, 430-436. [CrossRef] [PubMed]

38. Karczmarczyk, A.; Haupt, K.; Feller, K.H. Development of a QCM-D biosensor for Ochratoxin A detection in red wine. Talanta 2017, 166, 193-197. [CrossRef] [PubMed]

39. Lin, X.H.; Aik, S.X.L.; Angkasa, J.; Le, Q.; Chooi, K.S.; Li, S.F.Y. Selective and sensitive sensors based on molecularly imprinted poly(vinylidene fluoride) for determination of pesticides and chemical threat agent simulants. Sens. Actuators B Chem. 2018, 258, 228-237. [CrossRef]

40. Liu, X.; Hu, Y.; Sheng, X.; Peng, Y.; Bai, J.; Lv, Q.; Jia, H.; Jiang, H.; Gao, Z. Rapid high-throughput detection of diethylstilbestrol by using the arrayed langasite crystal microbalance combined with gold nanoparticles through competitive immunoassay. Sens. Actuators B Chem. 2017, 247, 245-253. [CrossRef]

41. Melani, V.; Haddada, M.B.; Moustaoui, H.; Landoulsi, J.; Djaker, N.; de la Chapelle, M.L.; Spadavecchia, J. Pegylated doxorubicin gold complex: From nanovector to potential intercalant agent for biosensor applications. Front. Lab. Med. 2017, 1, 114-121. [CrossRef]

42. Yuan, M.; Song, Z.; Fei, J.; Wang, X.; Xu, F.; Cao, H.; Yu, J. Aptasensor for lead (II) based on the use of a quartz crystal microbalance modified with gold nanoparticles. Microchim. Acta 2017, 184, 1397-1403. [CrossRef]

43. Shen, C.Y.; Lin, Y.M.; Hwang, R.C. Detection of $\mathrm{Cu}(\mathrm{II})$ ion in water using a quartz crystal microbalance. J. Electr. Electron. Eng. 2016, 4, 13-17. [CrossRef]

44. Teh, H.B.; Li, H.; Li, S.F.Y. Highly sensitive and selective detection of $\mathrm{Pb}^{2+}$ ions using a novel and simple DNAzyme-based quartz crystal microbalance with dissipation biosensor. Analyst 2014, 139, 5170-5175. [CrossRef] [PubMed]

45. Zhao, H.; Lin, L.; Tang, J.; Duan, M.; Jiang, L. Enhancement of the immobilization and discrimination of DNA probe on a biosensor using gold nanoparticles. Chin. Sci. Bull. 2001, 46, 1074-1077.

46. Liu, S.F.; Li, J.R.; Jiang, L. Surface modification of platinum quartz crystal microbalance by controlled electroless deposition of gold nanoparticles and its enhancing effect on the HS-DNA immobilization. Colloid Surf. A 2005, 257, 57-62. [CrossRef]

47. Li, S.; Xia, Y.; Zhang, J.; Han, J.; Jiang, L. Polystyrene spheres coated with gold nanoparticles for detection of DNA. Electrophoresis 2010, 31, 3090-3096. [CrossRef] [PubMed]

48. Liu, T.; Tang, J.A.; Han, M.; Jiang, L. A novel microgravimetric DNA sensor with high sensitivity. Biochem. Biophys. Res. Commun. 2003, 304, 98-100. [CrossRef]

49. Kim, N.H.; Baek, T.J.; Park, H.G.; Seong, G.H. Highly sensitive biomolecule detection on a quartz crystal microbalance using gold nanoparticles as signal amplification probes. Anal. Sci. 2007, 23, 177-181. [CrossRef] [PubMed]

50. Yan, Z.; Yang, M.; Wang, Z.; Zhang, F.; Xia, J.; Shi, G.; Xia, L.; Li, Y.; Xia, Y.; Xia, L. A label-free immunosensor for detecting common acute lymphoblastic leukemia antigen (CD10) based on gold nanoparticles by quartz crystal microbalance. Sens. Actuators B Chem. 2015, 210, 248-253. [CrossRef]

51. Zhao, H.Q.; Lin, L.; Li, J.R.; Tang, J.A.; Duan, M.X.; Jiang, L. DNA biosensor with high sensitivity amplified by gold nanoparticles. J. Nanopart. Res. 2001, 3, 321-323. [CrossRef]

52. Liu, T.; Tang, J.A.; Jiang, L. Sensitivity enhancement of DNA sensors by nanogold surface modification. Biochem. Biophys. Res. Commun. 2002, 295, 14-16. [CrossRef]

53. Liu, T.; Tang, J.A.; Jiang, L. The enhancement effect of gold nanoparticles as a surface modifier on DNA sensor sensitivity. Biochem. Biophys. Res. Commun. 2004, 313, 3-7. [CrossRef] [PubMed]

54. Premaratne, G.; Al Mubarak, Z.H.; Senavirathna, L.; Liu, L.; Krishnan, S. Measuring ultra-low levels of nucleotide biomarkers using quartz crystal microbalance and SPR microarray imaging methods: A comparative analysis. Sens. Actuators B Chem. 2017, 253, 368-375. [CrossRef] [PubMed] 
55. Chen, S.H.; Chuang, Y.C.; Lu, Y.C.; Lin, H.C.; Yang, Y.L.; Lin, C.S. A method of layer-by-layer gold nanoparticle hybridization in a quartz crystal microbalance DNA sensing system used to detect dengue virus. Nanotechnology 2009, 20, 215501. [CrossRef] [PubMed]

56. Kim, N.; Kim, D.K.; Cho, Y.J. Gold nanoparticle-based signal augmentation of quartz crystal microbalance immunosensor measuring C-reactive protein. Curr. Appl. Phys. 2010, 10, 1227-1230. [CrossRef]

57. Tang, D.; Zhang, B.; Tang, J.; Hou, L.; Chen, G. Displacement-type quartz crystal microbalance immunosensing platform for ultrasensitive monitoring of small molecular toxins. Anal. Chem. 2013, 85, 6958-6966. [CrossRef] [PubMed]

58. Shan, W.; Pan, Y.; Fang, H.; Guo, M.; Nie, Z.; Huang, Y.; Yao, S. An aptamer-based quartz crystal microbalance biosensor for sensitive and selective detection of leukemia cells using silver-enhanced gold nanoparticle label. Talanta 2014, 126, 130-135. [CrossRef] [PubMed]

59. Song, W.; Guo, X.; Sun, W.; Yin, W.; He, P.; Yang, X.; Zhang, X. Target-triggering multiple-cycle signal amplification strategy for ultrasensitive detection of DNA based on QCM and SPR. Anal. Biochem. 2018, 553, 57-61. [CrossRef] [PubMed]

60. García, M.G.; García, A.C. Adsorptive stripping voltammetric behaviour of colloidal gold and immunogold on carbon paste electrode. Biosens. Bioelectron. 1995, 38, 389-395.

61. Ozsoz, M.; Erdem, A.; Kerman, K.; Ozkan, D.; Tugrul, B.; Topcuoglu, N.; Ekren, H.; Taylan, M. Electrochemical genosensor based on colloidal gold nanoparticles for the detection of Factor V Leiden mutation using disposable pencil graphite electrodes. Anal. Chem. 2003, 75, 2181-2187. [CrossRef] [PubMed]

62. Afonso, A.S.; Pérez-López, B.; Faria, R.C.; Mattoso, L.H.; Hernández-Herrero, M.; Roig-Sagués, A.X.; Costa, M.M.; Merkoçi, A. Electrochemical detection of Salmonella using gold nanoparticles. Biosens. Bioelectron. 2013, 40, 121-126. [CrossRef] [PubMed]

63. Zheng, J.; Feng, W.; Lin, L.; Zhang, F.; Cheng, G.; He, P.; Fang, Y. A new amplification strategy for ultrasensitive electrochemical aptasensor with network-like thiocyanuric acid/gold nanoparticles. Biosens. Bioelectron. 2007, 23, 341-347. [CrossRef] [PubMed]

64. Pumera, M.; Castaneda, M.T.; Pividori, M.I.; Eritja, R.; Merkoçi, A.; Alegret, S. Magnetically trigged direct electrochemical detection of DNA hybridization using $\mathrm{Au}_{67}$ quantum dot as electrical tracer. Langmuir 2005, 21, 9625-9629. [CrossRef] [PubMed]

65. Ambrosi, A.; Castañeda, M.T.; Killard, A.J.; Smyth, M.R.; Alegret, S.; Merkoçi, A. Double-codified gold nanolabels for enhanced immunoanalysis. Anal. Chem. 2007, 79, 5232-5240. [CrossRef] [PubMed]

66. Lau, H.Y.; Wu, H.; Wee, E.J.; Trau, M.; Wang, Y.; Botella, J.R. Specific and sensitive isothermal electrochemical biosensor for plant pathogen DNA detection with colloidal gold nanoparticles as probes. Sci. Rep. 2017, 7, 38896. [CrossRef] [PubMed]

67. Wang, Y.; Alocilja, E.C. Gold nanoparticle-labeled biosensor for rapid and sensitive detection of bacterial pathogens. J. Biol. Eng. 2015, 9, 16. [CrossRef] [PubMed]

68. Rochelet-Dequaire, M.; Limoges, B.; Brossier, P. Subfemtomolar electrochemical detection of target DNA by catalytic enlargement of the hybridized gold nanoparticle labels. Analyst 2006, 131, 923-929. [CrossRef] [PubMed]

69. Authier, L.; Grossiord, C.; Brossier, P. Gold nanoparticle-based quantitative electrochemical detection of amplified human cytomegalovirus DNA using disposable microband electrodes. Anal. Chem. 2001, 73, 4450-4456. [CrossRef] [PubMed]

70. Kerman, K.; Morita, Y.; Takamura, Y.; Ozsoz, M.; Tamiya, E. Modification of Escherichia coli single-stranded DNA binding protein with gold nanoparticles for electrochemical detection of DNA hybridization. Anal. Chim. Acta 2004, 510, 169-174. [CrossRef]

71. Ng, B.Y.; Xiao, W.; West, N.P.; Wee, E.J.; Wang, Y.; Trau, M. Rapid, single-cell electrochemical detection of Mycobacterium tuberculosis using colloidal gold nanoparticles. Anal. Chem. 2015, 87, 10613-10618. [CrossRef] [PubMed]

72. Ilkhani, H.; Sarparast, M.; Noori, A.; Bathaie, S.Z.; Mousavi, M.F. Electrochemical aptamer/antibody based sandwich immunosensor for the detection of EGFR, a cancer biomarker, using gold nanoparticles as a signaling probe. Biosens. Bioelectron. 2015, 74, 491-497. [CrossRef] [PubMed]

73. Qin, X.; Xu, A.; Liu, L.; Deng, W.; Chen, C.; Tan, Y.; Fu, Y.; Xie, Q.; Yao, S. Ultrasensitive electrochemical immunoassay of proteins based on in situ duple amplification of gold nanoparticle biolabel signals. Chem. Commun. 2015, 51, 8540-8543. [CrossRef] [PubMed] 
74. López-Marzo, A.M.; Hoyos-de-la-Torre, R.; Baldrich, E. $\mathrm{NaNO}_{3} / \mathrm{NaCl}$ Oxidant and Polyethylene Glycol (PEG) Capped Gold Nanoparticles (AuNPs) as a Novel Green Route for AuNPs Detection in Electrochemical Biosensors. Anal. Chem. 2018, 90, 4010-4018. [CrossRef] [PubMed]

75. Brown, K.R.; Fox, A.P.; Natan, M.J. Morphology-dependent electrochemistry of cytochrome c at Au colloid-modified $\mathrm{SnO}_{2}$ electrodes. J. Am. Chem. Soc. 1996, 118, 1154-1157. [CrossRef]

76. Heydari-Bafrooei, E.; Shamszadeh, N.S. Electrochemical bioassay development for ultrasensitive aptasensing of prostate specific antigen. Biosens. Bioelectron. 2017, 91, 284-292. [CrossRef] [PubMed]

77. Wang, W.; Ma, C.; Li, Y.; Liu, B.; Tan, L. One-pot preparation of conducting composite containing abundant amino groups on electrode surface for electrochemical detection of von willebrand factor. Appl. Surf. Sci. 2018, 433, 847-854. [CrossRef]

78. Zhang, Y.; Xiao, J.; Sun, Y.; Wang, L.; Dong, X.; Ren, J.; He, W.; Xiao, F. Flexible nanohybrid microelectrode based on carbon fiber wrapped by gold nanoparticles decorated nitrogen doped carbon nanotube arrays: In situ electrochemical detection in live cancer cells. Biosens. Bioelectron. 2018, 100, 453-461. [CrossRef] [PubMed]

79. Vural, T.; Yaman, Y.T.; Ozturk, S.; Abaci, S.; Denkbas, E.B. Electrochemical immunoassay for detection of prostate specific antigen based on peptide nanotube-gold nanoparticle-polyaniline immobilized pencil graphite electrode. J. Colloid Interface Sci. 2018, 510, 318-326. [CrossRef] [PubMed]

80. Del Caño, R.; Mateus, L.; Sánchez-Obrero, G.; Sevilla, J.M.; Madueno, R.; Blazquez, M.; Pineda, T. Hemoglobin becomes electroactive upon interaction with surface-protected Au nanoparticles. Talanta 2018, 176, 667-673. [CrossRef] [PubMed]

81. Zhao, L.; Ma, Z. New immunoprobes based on bovine serum albumin-stabilized copper nanoclusters with triple signal amplification for ultrasensitive electrochemical immunosensing for tumor marker. Sens. Actuators B Chem. 2017, 241, 849-854. [CrossRef]

82. Bao, J.; Geng, X.; Hou, C.; Zhao, Y.; Huo, D.; Wang, Y.; Wang, Z.; Zeng, Y.; Yang, M.; Fa, H. A simple and universal electrochemical assay for sensitive detection of DNA methylation, methyltransferase activity and screening of inhibitors. J. Electroanal. Chem. 2018, 814, 144-152. [CrossRef]

83. Jarocka, U.; Sawicka, R.; Góra-Sochacka, A.; Sirko, A.; Zagórski-Ostoja, W.; Radecki, J.; Radecka, H. An immunosensor based on antibody binding fragments attached to gold nanoparticles for the detection of peptides derived from avian influenza hemagglutinin H5. Sensors 2014, 14, 15714-15728. [CrossRef] [PubMed]

84. Wang, X.; Du, D.; Dong, H.; Song, S.; Koh, K.; Chen, H. para-Sulfonatocalix[4]arene stabilized gold nanoparticles multilayers interfaced to electrodes through host-guest interaction for sensitive ErbB ${ }_{2}$ detection. Biosens. Bioelectron. 2018, 99, 375-381. [CrossRef] [PubMed]

85. Wang, L.; Hua, E.; Liang, M.; Ma, C.; Liu, Z.; Sheng, S.; Liu, M.; Xie, G.; Feng, W. Graphene sheets, polyaniline and AuNPs based DNA sensor for electrochemical determination of BCR/ABL fusion gene with functional hairpin probe. Biosens. Bioelectron. 2014, 51, 201-207. [CrossRef] [PubMed]

86. Gao, Y.S.; Zhu, X.F.; Xu, J.K.; Lu, L.M.; Wang, W.M.; Yang, T.T.; Xing, H.K.; Yu, Y.F. Label-free electrochemical immunosensor based on Nile blue A-reduced graphene oxide nanocomposites for carcinoembryonic antigen detection. Anal. Biochem. 2016, 500, 80-87. [CrossRef] [PubMed]

87. Shuai, H.L.; Huang, K.J.; Xing, L.L.; Chen, Y.X. Ultrasensitive electrochemical sensing platform for microRNA based on tungsten oxide-graphene composites coupling with catalyzed hairpin assembly target recycling and enzyme signal amplification. Biosens. Bioelectron. 2016, 86, 337-345. [CrossRef] [PubMed]

88. Bai, L.; Yuan, R.; Chai, Y.; Zhuo, Y.; Yuan, Y.; Wang, Y. Simultaneous electrochemical detection of multiple analytes based on dual signal amplification of single-walled carbon nanotubes and multi-labeled graphene sheets. Biomaterials 2012, 33, 1090-1096. [CrossRef] [PubMed]

89. Liu, B.; Lu, L.; Hua, E.; Jiang, S.; Xie, G. Detection of the human prostate-specific antigen using an aptasensor with gold nanoparticles encapsulated by graphitized mesoporous carbon. Microchim. Acta 2012, 178, 163-170. [CrossRef]

90. Jeong, B.; Akter, R.; Han, O.H.; Rhee, C.K.; Rahman, M.A. Increased electrocatalyzed performance through dendrimer-encapsulated gold nanoparticles and carbon nanotube-assisted multiple bienzymatic labels: Highly sensitive electrochemical immunosensor for protein detection. Anal. Chem. 2013, 85, 1784-1791. [CrossRef] [PubMed] 
91. Zhang, X.; Shen, J.; Ma, H.; Jiang, Y.; Huang, C.; Han, E.; Yao, B.; He, Y. Optimized dendrimer-encapsulated gold nanoparticles and enhanced carbon nanotube nanoprobes for amplified electrochemical immunoassay of E. coli in dairy product based on enzymatically induced deposition of polyaniline. Biosens. Bioelectron. 2016, 80, 666-673. [CrossRef] [PubMed]

92. Riskin, M.; Tel-Vered, R.; Bourenko, T.; Granot, E.; Willner, I. Imprinting of molecular recognition sites through electropolymerization of functionalized Au nanoparticles: Development of an electrochemical TNT sensor based on $\pi$-donor-acceptor interactions. J. Am. Chem. Soc. 2008, 130, 9726-9733. [CrossRef] [PubMed]

93. Yang, H.; Li, L.; Ding, Y.; Ye, D.; Wang, Y.; Cui, S.; Liao, L. Molecularly imprinted electrochemical sensor based on bioinspired Au microflowers for ultra-trace cholesterol assay. Biosens. Bioelectron. 2017, 92, 748-754. [CrossRef] [PubMed]

94. Sun, D.; Lu, J.; Zhong, Y.; Yu, Y.; Wang, Y.; Zhang, B.; Chen, Z. Sensitive electrochemical aptamer cytosensor for highly specific detection of cancer cells based on the hybrid nanoelectrocatalysts and enzyme for signal amplification. Biosens. Bioelectron. 2016, 75, 301-307. [CrossRef] [PubMed]

95. Wang, J.; Li, J.; Baca, A.J.; Hu, J.; Zhou, F.; Yan, W.; Pang, D.W. Amplified voltammetric detection of DNA hybridization via oxidation of ferrocene caps on gold nanoparticle/streptavidin conjugates. Anal. Chem. 2003, 75, 3941-3945. [CrossRef] [PubMed]

96. Miao, X.; Wang, W.; Kang, T.; Liu, J.; Shiu, K.K.; Leung, C.H.; Ma, D.L. Ultrasensitive electrochemical detection of miRNA-21 by using an iridium(III) complex as catalyst. Biosens. Bioelectron. 2016, 86, 454-458. [CrossRef] [PubMed]

97. Hu, K.; Lan, D.; Li, X.; Zhang, S. Electrochemical DNA biosensor based on nanoporous gold electrode and multifunctional encoded DNA-Au bio bar codes. Anal. Chem. 2008, 80, 9124-9130. [CrossRef] [PubMed]

98. Shi, L.; Rong, X.; Wang, Y.; Ding, S.; Tang, W. High-performance and versatile electrochemical aptasensor based on self-supported nanoporous gold microelectrode and enzyme-induced signal amplification. Biosens. Bioelectron. 2018, 102, 41-48. [CrossRef] [PubMed]

99. Zong, Y.; Liu, F.; Zhang, Y.; Zhan, T.; He, Y.; Hun, X. Signal amplification technology based on entropy-driven molecular switch for ultrasensitive electrochemical determination of DNA and Salmonella typhimurium. Sens. Actuators B Chem. 2016, 225, 420-427. [CrossRef]

100. Zhao, J.; Zhang, Y.; Li, H.; Wen, Y.; Fan, X.; Lin, F.; Tan, L.; Yao, S. Ultrasensitive electrochemical aptasensor for thrombin based on the amplification of aptamer-AuNPs-HRP conjugates. Biosens. Bioelectron. 2011, 26, 2297-2303. [CrossRef] [PubMed]

101. Zhou, Y.; Yin, H.; Li, X.; Li, Z.; Ai, S.; Lin, H. Electrochemical biosensor for protein kinase A activity assay based on gold nanoparticles-carbon nanospheres, phos-tag-biotin and $\beta$-galactosidase. Biosens. Bioelectron. 2016, 86, 508-515. [CrossRef] [PubMed]

102. Liu, L.; Xia, N.; Liu, H.; Kang, X.; Liu, X.; Xue, C.; He, X. Highly sensitive and label-free electrochemical detection of microRNAs based on triple signal amplification of multifunctional gold nanoparticles, enzymes and redox-cycling reaction. Biosens. Bioelectron. 2014, 53, 399-405. [CrossRef] [PubMed]

103. Chen, Y.X.; Huang, K.J.; Lin, F.; Fang, L.X. Ultrasensitive electrochemical sensing platform based on graphene wrapping $\mathrm{SnO}_{2}$ nanocorals and autonomous cascade DNA duplication strategy. Talanta 2017, 175, 168-176. [CrossRef] [PubMed]

104. Yin, H.; Zhou, Y.; Zhang, H.; Meng, X.; Ai, S. Electrochemical determination of microRNA-21 based on graphene, LNA integrated molecular beacon, AuNPs and biotin multifunctional bio bar codes and enzymatic assay system. Biosens. Bioelectron. 2012, 33, 247-253. [CrossRef] [PubMed]

105. Wang, Z.; Zhang, J.; Zhu, C.; Wu, S.; Mandler, D.; Marks, R.S.; Zhang, H. Amplified detection of femtomolar DNA based on a one-to-few recognition reaction between DNA-Au conjugate and target DNA. Nanoscale 2014, 6, 3110-3115. [CrossRef] [PubMed]

106. Shu, H.; Wen, W.; Xiong, H.; Zhang, X.; Wang, S. Novel electrochemical aptamer biosensor based on gold nanoparticles signal amplification for the detection of carcinoembryonic antigen. Electrochem. Commun. 2013, 37, 15-19. [CrossRef]

107. Hasanzadeh, M.; Babaie, P.; Mokhtarzadeh, A.; Hajizadeh, N.; Mahboob, S. A novel DNA based bioassay toward ultrasensitive detection of Brucella using gold nanoparticles supported histidine: A new platform for the assay of bacteria in the cultured and human biofluids with and without polymerase chain reactions (PCR). Int. J. Biol. Macromol. 2018, 120, 422-430. [CrossRef] [PubMed] 
108. Wang, J.; Ma, K.; Yin, H.; Zhou, Y.; Ai, S. Aptamer based voltammetric determination of ampicillin using a single-stranded DNA binding protein and DNA functionalized gold nanoparticles. Microchim. Acta 2018, 185, 68. [CrossRef] [PubMed]

109. Chen, S.; Liu, P.; Su, K.; Li, X.; Qin, Z.; Xu, W.; Chen, J.; Li, C.; Qiu, J. Electrochemical aptasensor for thrombin using co-catalysis of hemin/G-quadruplex DNAzyme and octahedral $\mathrm{Cu}_{2} \mathrm{O}$-Au nanocomposites for signal amplification. Biosens. Bioelectron. 2018, 99, 338-345. [CrossRef] [PubMed]

110. Wang, W.J.; Li, J.J.; Rui, K.; Gai, P.P.; Zhang, J.R.; Zhu, J.J. Sensitive electrochemical detection of telomerase activity using spherical nucleic acids gold nanoparticles triggered mimic-hybridization chain reaction enzyme-free dual signal amplification. Anal. Chem. 2015, 87, 3019-3026. [CrossRef] [PubMed]

111. Bo, B.; Zhang, T.; Jiang, Y.; Cui, H.; Miao, P. Triple Signal Amplification Strategy for Ultrasensitive Determination of miRNA Based on Duplex Specific Nuclease and Bridge DNA-Gold Nanoparticles. Anal. Chem. 2018, 90, 2395-2400. [CrossRef] [PubMed]

112. Yu, S.; Wang, Y.; Jiang, L.P.; Bi, S.; Zhu, J.J. Cascade amplification-mediated in situ hot-spot assembly for microRNA detection and molecular logic gate operations. Anal. Chem. 2018, 90, 4544-4551. [CrossRef] [PubMed]

113. Wang, J.; Lu, Z.; Tang, H.; Wu, L.; Wang, Z.; Wu, M.; Yi, X.; Wang, J. Multiplexed electrochemical detection of MiRNAs from sera of glioma patients at different stages via the novel conjugates of conducting magnetic microbeads and Diblock oligonucleotide-modified gold nanoparticles. Anal. Chem. 2017, 89, 10834-10840. [CrossRef] [PubMed]

114. Lou, Y.; Maye, M.M.; Han, L.; Luo, J.; Zhong, C.J. Gold-platinum alloy nanoparticle assembly as catalyst for methanol electrooxidation. Chem. Commun. 2001, 0, 473-474. [CrossRef]

115. Valden, M.; Lai, X.; Goodman, D.W. Onset of catalytic activity of gold clusters on titania with the appearance of nonmetallic properties. Science 1998, 281, 1647-1650. [CrossRef] [PubMed]

116. El-Deab, M.S.; Okajima, T.; Ohsaka, T. Electrochemical reduction of oxygen on gold nanoparticleelectrodeposited glassy carbon electrodes. J. Electrochem. Soc. 2003, 150, A851-A857. [CrossRef]

117. De la Escosura-Muñiz, A.; Baptista-Pires, L.; Serrano, L.; Altet, L.; Francino, O.; Sánchez, A.; Merkoçi, A. Magnetic Bead/Gold Nanoparticle Double-Labeled Primers for Electrochemical Detection of Isothermal Amplified Leishmania DNA. Small 2016, 12, 205-213. [CrossRef] [PubMed]

118. Qu, H.; Yang, L.; Yu, J.; Wang, L.; Liu, H. Host-guest Interaction Induced Rapid Self-assembled $\mathrm{Fe}_{3} \mathrm{O}_{4} @ \mathrm{Au}$ Nanoparticles with High Catalytic Activity. Ind. Eng. Chem. Res. 2018, 57, 9448-9456. [CrossRef]

119. Zheng, X.; Li, L.; Cui, K.; Zhang, Y.; Zhang, L.; Ge, S.; Yu, J. Ultrasensitive Enzyme-free Biosensor by Coupling Cyclodextrin Functionalized Au Nanoparticles and High-Performance Au-Paper Electrode. ACS Appl. Mater. Interfaces 2018, 10, 3333-3340. [CrossRef] [PubMed]

120. Rao, H.; Liu, Y.; Zhong, J.; Zhang, Z.; Zhao, X.; Liu, X.; Jiang, Y.; Zou, P.; Wang, X.; Wang, Y. Gold nanoparticle/chitosan@N,S co-doped multiwalled carbon nanotubes sensor: Fabrication, characterization, and electrochemical detection of catechol and nitrite. ACS Sustain. Chem. Eng. 2017, 5, 10926-10939. [CrossRef]

121. Jena, B.K.; Raj, C.R. Electrochemical biosensor based on integrated assembly of dehydrogenase enzymes and gold nanoparticles. Anal. Chem. 2006, 78, 6332-6339. [CrossRef] [PubMed]

122. Li, F.; Han, J.; Jiang, L.; Wang, Y.; Li, Y.; Dong, Y.; Wei, Q. An ultrasensitive sandwich-type electrochemical immunosensor based on signal amplification strategy of gold nanoparticles functionalized magnetic multi-walled carbon nanotubes loaded with lead ions. Biosens. Bioelectron. 2015, 68, 626-632. [CrossRef] [PubMed]

123. Cao, X.; Xu, J.; Xia, J.; Zhang, F.; Wang, Z. An electrochemical aptasensor based on the conversion of liquid-phase colorimetric assay into electrochemical analysis for sensitive detection of lysozyme. Sens. Actuators B Chem. 2018, 255, 2136-2142. [CrossRef]

124. Lin, L.; Liu, Y.; Tang, L.; Li, J. Electrochemical DNA sensor by the assembly of graphene and DNA-conjugated gold nanoparticles with silver enhancement strategy. Analyst 2011, 136, 4732-4737. [CrossRef] [PubMed]

125. Lin, D.; Wu, J.; Wang, M.; Yan, F.; Ju, H. Triple signal amplification of graphene film, polybead carried gold nanoparticles as tracing tag and silver deposition for ultrasensitive electrochemical immunosensing. Anal. Chem. 2012, 84, 3662-3668. [CrossRef] [PubMed] 
126. Min, I.H.; Choi, L.; Ahn, K.S.; Kim, B.K.; Lee, B.Y.; Kim, K.S.; Choi, H.N.; Lee, W.Y. Electrochemical determination of carbohydrate-binding proteins using carbohydrate-stabilized gold nanoparticles and silver enhancement. Biosens. Bioelectron. 2010, 26, 1326-1331. [CrossRef] [PubMed]

127. Cai, H.; Wang, Y.; He, P.; Fang, Y. Electrochemical detection of DNA hybridization based on silver-enhanced gold nanoparticle label. Anal. Chim. Acta 2002, 469, 165-172. [CrossRef]

128. Wang, J.; Xu, D.; Polsky, R. Magnetically-induced solid-state electrochemical detection of DNA hybridization. J. Am. Chem. Soc. 2002, 124, 4208-4209. [CrossRef] [PubMed]

129. Cai, H.; Xu, Y.; Zhu, N.; He, P.; Fang, Y. An electrochemical DNA hybridization detection assay based on a silver nanoparticle label. Analyst 2002, 127, 803-808. [CrossRef] [PubMed]

130. Wang, J.; Polsky, R.; Xu, D. Silver-enhanced colloidal gold electrochemical stripping detection of DNA hybridization. Langmuir 2001, 17, 5739-5741. [CrossRef]

131. Pan, Y.; Shan, W.; Fang, H.; Guo, M.; Nie, Z.; Huang, Y.; Yao, S. Sensitive and visible detection of apoptotic cells on Annexin-V modified substrate using aminophenylboronic acid modified gold nanoparticles (APBA-GNPs) labeling. Biosens. Bioelectron. 2014, 52, 62-68. [CrossRef] [PubMed]

132. Lai, G.; Yan, F.; Wu, J.; Leng, C.; Ju, H. Ultrasensitive multiplexed immunoassay with electrochemical stripping analysis of silver nanoparticles catalytically deposited by gold nanoparticles and enzymatic reaction. Anal. Chem. 2011, 83, 2726-2732. [CrossRef] [PubMed]

133. Zhang, J.; Xiong, Z.; Chen, Z. Ultrasensitive electrochemical microcystin-LR immunosensor using gold nanoparticle functional polypyrrole microsphere catalyzed silver deposition for signal amplification. Sens. Actuators B Chem. 2017, 246, 623-630. [CrossRef]

134. Yang, Y.; Yan, Q.; Liu, Q.; Li, Y.; Liu, H.; Wang, P.; Chen, L.; Zhang, D.; Li, Y.; Dong, Y. An ultrasensitive sandwich-type electrochemical immunosensor based on the signal amplification strategy of echinoidea-shaped $\mathrm{Au} @ \mathrm{Ag}-\mathrm{Cu}_{2} \mathrm{O}$ nanoparticles for prostate specific antigen detection. Biosens. Bioelectron. 2018, 99, 450-457. [CrossRef] [PubMed]

135. Duangkaew, P.; Wutikhun, T.; Laocharoensuk, R. Triple signal amplification strategy based on size and shape transformation of ultrasmall sub-10 nm gold nanoparticles tag towards sensitivity improvement of electrochemical immunosensors. Sens. Actuators B Chem. 2017, 239, 430-437. [CrossRef]

136. Houk, R.S.; Fassel, V.A.; Flesch, G.D.; Svec, H.J.; Gray, A.L.; Taylor, C.E. Inductively coupled argon plasma as an ion source for mass spectrometric determination of trace elements. Anal. Chem. 1980, 52, 2283-2289. [CrossRef]

137. Yuan, H.; Gao, S.; Liu, X.; Li, H.; Günther, D.; Wu, F. Accurate U-Pb age and trace element determinations of zircon by laser ablation-inductively coupled plasma-mass spectrometry. Geostand. Geoanal. Res. 2004, 28, 353-370. [CrossRef]

138. Jenner, G.A.; Longerich, H.P.; Jackson, S.E.; Fryer, B.J. ICP-MS-A powerful tool for high-precision trace-element analysis in earth sciences: Evidence from analysis of selected USGS reference samples. Chem. Geol. 1990, 83, 133-148. [CrossRef]

139. Jackson, S.E.; Pearson, N.J.; Griffin, W.L.; Belousova, E.A. The application of laser ablation-inductively coupled plasma-mass spectrometry to in situ U-Pb zircon geochronology Fryer. Chem. Geol. 2004, 211, 47-69. [CrossRef]

140. Becker, J.S.; Zoriy, M.; Matusch, A.; Wu, B.; Salber, D.; Palm, C.; Becker, J.S. Bioimaging of metals by laser ablation inductively coupled plasma mass spectrometry (LA-ICP-MS). Mass Spectrom. Rev. 2010, 29, 156-175. [CrossRef] [PubMed]

141. Jarujamrus, P.; Chawengkirttikul, R.; Shiowatana, J.; Siripinyanond, A. Towards chloramphenicol detection by inductively coupled plasma mass spectrometry (ICP-MS) linked immunoassay using gold nanoparticles (AuNPs) as element tags. Anal. At. Spectrom. 2012, 27, 884-890. [CrossRef]

142. Li, X.; Zhou, H.; Yang, L.; Du, G.; Pai-Panandiker, A.S.; Huang, X.; Yan, B. Enhancement of cell recognition in vitro by dual-ligand cancer targeting gold nanoparticles. Biomaterials 2011, 32, 2540-2545. [CrossRef] [PubMed]

143. Lin, Y.; Hamme II, A.T. Gold nanoparticle labeling based ICP-MS detection/measurement of bacteria, and their quantitative photothermal destruction. Mater. Chem. B 2015, 3, 3573-3582. [CrossRef] [PubMed]

144. Dersch, J.M.; Nguyen, T.T.; Østergaard, J.; Stürup, S.; Gammelgaard, B. Selective analysis of human serum albumin based on SEC-ICP-MS after labelling with iophenoxic acid. Anal. Bioanal. Chem. 2015, 407, 2829-2836. [CrossRef] [PubMed] 
145. Jeong, A.; Lim, H.B. Magnetophoretic separation ICP-MS immunoassay using Cs-doped multicore magnetic nanoparticles for the determination of salmonella typhimurium. Talanta 2018, 178, 916-921. [CrossRef] [PubMed]

146. Garcia-Cortes, M.; Encinar, J.R.; Costa-Fernandez, J.M.; Sanz-Medel, A. Highly sensitive nanoparticle-based immunoassays with elemental detection: Application to Prostate-Specific Antigen quantification. Biosens. Bioelectron. 2016, 85, 128-134. [CrossRef] [PubMed]

147. Luo, Y.; Yan, X.; Huang, Y.; Wen, R.; Li, Z.; Yang, L.; Yang, C.J.; Wang, Q. ICP-MS-based multiplex and ultrasensitive assay of viruses with lanthanide-coded biospecific tagging and amplification strategies. Anal. Chem. 2013, 85, 9428-9432. [CrossRef] [PubMed]

148. Merkoçi, A.; Aldavert, M.; Tarrasón, G.; Eritja, R.; Alegret, S. Toward an ICPMS-linked DNA assay based on gold nanoparticles immunoconnected through peptide sequences. Anal. Chem. 2005, 77, 6500-6503. [CrossRef] [PubMed]

149. Zhang, C.; Zhang, Z.; Yu, B.; Shi, J.; Zhang, X. Application of the biological conjugate between antibody and colloid Au nanoparticles as analyte to inductively coupled plasma mass spectrometry. Anal. Chem. 2002, 74, 96-99. [CrossRef] [PubMed]

150. Quinn, Z.A.; Baranov, V.I.; Tanner, S.D.; Wrana, J.L. Simultaneous determination of proteins using an element-tagged immunoassay coupled with ICP-MS detection. J. Anal. At. Spectrom. 2002, 17, 892-896. [CrossRef]

151. Hsu, I.H.; Chen, W.H.; Wu, T.K.; Sun, Y.C. Gold nanoparticle-based inductively coupled plasma mass spectrometry amplification and magnetic separation for the sensitive detection of a virus-specific RNA sequence. J. Chromatogr. A 2011, 1218, 1795-1801. [CrossRef] [PubMed]

152. Zhang, X.; Chen, B.; He, M.; Zhang, Y.; Xiao, G.; Hu, B. Magnetic immunoassay coupled with inductively coupled plasma mass spectrometry for simultaneous quantification of alpha-fetoprotein and carcinoembryonic antigen in human serum. Spectrochim. Acta B 2015, 106, 20-27. [CrossRef]

153. He, Q.; Zhu, Z.; Jin, L.; Peng, L.; Guo, W.; Hu, S. Detection of HIV-1 p24 antigen using streptavidin-biotin and gold nanoparticles based immunoassay by inductively coupled plasma mass spectrometry. J. Anal. At. Spectrom. 2014, 29, 1477-1482. [CrossRef]

154. Zhang, X.; Chen, B.; He, M.; Zhang, Y.; Peng, L.; Hu, B. Boronic acid recognition based-gold nanoparticle-labeling strategy for the assay of sialic acid expression on cancer cell surface by inductively coupled plasma mass spectrometry. Analyst 2016, 141, 1286-1293. [CrossRef] [PubMed]

155. Yang, W.; Xi, Z.; Zeng, X.; Fang, L.; Jiang, W.; Wu, Y.; Xu, L.; Fu, F. Magnetic bead-based AuNP labelling combined with inductively coupled plasma mass spectrometry for sensitively and specifically counting cancer cells. J. Anal. At. Spectrom. 2016, 31, 679-685. [CrossRef]

156. Li, X.; Chen, B.; He, M.; Xiao, G.; Hu, B. Gold nanoparticle labeling with tyramide signal amplification for highly sensitive detection of alpha fetoprotein in human serum by ICP-MS. Talanta 2018, 176, 40-46. [CrossRef] [PubMed]

157. He, Y.; Chen, D.; Li, M.; Fang, L.; Yang, W.; Xu, L.; Fu, F. Rolling circle amplification combined with gold nanoparticles-tag for ultra sensitive and specific quantification of DNA by inductively coupled plasma mass spectrometry. Biosens. Bioelectron. 2014, 58, 209-213. [CrossRef] [PubMed]

158. Zhang, X.; Chen, B.; He, M.; Wang, H.; Hu, B. Gold nanoparticles labeling with hybridization chain reaction amplification strategy for the sensitive detection of HepG2 cells by inductively coupled plasma mass spectrometry. Biosens. Bioelectron. 2016, 86, 736-740. [CrossRef] [PubMed]

159. Li, X.M.; Luo, J.; Zhang, N.B.; Wei, Q.L. Nucleic acid quantification using nicking-displacement, rolling circle amplification and bio-bar-code mediated triple-amplification. Anal. Chim. Acta 2015, 881, 117-123. [CrossRef] [PubMed]

160. Liu, J.M.; Li, Y.; Jiang, Y.; Yan, X.P. Gold nanoparticles amplified ultrasensitive quantification of human urinary protein by capillary electrophoresis with on-line inductively coupled plasma mass spectroscopic detection. J. Proteome Res. 2010, 9, 3545-3550. [CrossRef] [PubMed]

161. Degueldre, C.; Favarger, P.Y.; Wold, S. Gold colloid analysis by inductively coupled plasma-mass spectrometry in a single particle mode. Anal. Chim. Acta 2006, 555, 263-268. [CrossRef]

162. Degueldre, C.; Favarger, P.Y. Thorium colloid analysis by single particle inductively coupled plasma-mass spectrometry. Talanta 2004, 62, 1051-1054. [CrossRef] [PubMed] 
163. Beermann, B.; Carrillo-Nava, E.; Scheffer, A.; Buscher, W.; Jawalekar, A.M.; Seela, F.; Hinz, H.J. Association temperature governs structure and apparent thermodynamics of DNA-gold nanoparticles. Biophys. Chem. 2007, 126, 124-131. [CrossRef] [PubMed]

164. Helfrich, A.; Brüchert, W.; Bettmer, J. Size characterisation of Au nanoparticles by ICP-MS coupling techniques. J. Anal. At. Spectrom. 2006, 21, 431-434. [CrossRef]

165. Bao, D.; Oh, Z.G.; Chen, Z. Characterization of silver nanoparticles internalized by Arabidopsis plants using single particle ICP-MS analysis. Front. Plant. Sci. 2016, 7, 1-8. [CrossRef] [PubMed]

166. Gunduz, N.; Ceylan, H.; Guler, M.O.; Tekinay, A.B. Intracellular accumulation of gold nanoparticles leads to inhibition of macropinocytosis to reduce the endoplasmic reticulum stress. Sci. Rep. 2017, 7, 40493. [CrossRef] [PubMed]

167. Hou, S.; Sikora, K.N.; Tang, R.; Liu, Y.; Lee, Y.W.; Kim, S.T.; Jiang, Z.; Vachet, R.W.; Rotello, V.M.; Rotello, V.M. Quantitative differentiation of cell surface-bound and internalized cationic gold nanoparticles using mass spectrometry. ACS Nano 2016, 10, 6731-6736. [CrossRef] [PubMed]

168. Tavares, A.J.; Poon, W.; Zhang, Y.N.; Dai, Q.; Besla, R.; Ding, D.; Ouyang, B.; Li, A.; Chen, J.; Zheng, J.; et al. Effect of removing Kupffer cells on nanoparticle tumor delivery. Proc. Natl. Acad. Sci. USA 2017, 114, E10871-E10880. [CrossRef] [PubMed]

169. Kim, Y.H.; Min, K.H.; Wang, Z.; Kim, J.; Jacobson, O.; Huang, P.; Zhu, G.; Liu, Y.; Yung, B.; Niu, G.; et al. Development of Sialic Acid-coated Nanoparticles for Targeting Cancer and Efficient Evasion of the Immune System. Theranostics 2017, 7, 962-973. [CrossRef] [PubMed]

170. Zazo, H.; Colino, C.I.; Warzecha, K.T.; Hoss, M.; Gbureck, U.; Trautwein, C.; Tacke, F.; Lanao, J.M.; Bartneck, M. Gold Nanocarriers for Macrophage-Targeted Therapy of Human Immunodeficiency Virus. Macromol. Biosci. 2017, 17, 1600359. [CrossRef] [PubMed]

171. Allabashi, R.; Stach, W.; de la Escosura-Muñiz, A.; Liste-Calleja, L.; Merkoçi, A. ICP-MS: A powerful technique for quantitative determination of gold nanoparticles without previous dissolving. J. Nanopart. Res. 2009, 11, 2003. [CrossRef]

172. Liu, J.; Murphy, K.E.; MacCuspie, R.I.; Winchester, M.R. Capabilities of single particle inductively coupled plasma mass spectrometry for the size measurement of nanoparticles: A case study on gold nanoparticles. Anal. Chem. 2014, 86, 3405-3414. [CrossRef] [PubMed]

173. Han, G.; Xing, Z.; Dong, Y.; Zhang, S.; Zhang, X. One-step homogeneous DNA assay with single-nanoparticle detection. Angew. Chem. 2011, 123, 3524-3527. [CrossRef]

174. Zhu, D.; Liu, W.; Zhao, D.; Hao, Q.; Li, J.; Huang, J.; Shi, J.; Chao, J.; Su, S.; Wang, L. Label-Free Electrochemical Sensing Platform for MicroRNA-21 Detection Using Thionine and Gold Nanoparticles Co-Functionalized $\mathrm{MoS}_{2}$ Nanosheet. ACS. Appl. Mater. Interfaces 2017, 9, 35597-35603. [CrossRef] [PubMed]

175. Yang, H.; Jiang, P.; Chen, Z.; Nie, L. Magnetic $\mathrm{Fe}_{3} \mathrm{O}_{4} @$ Mesoporous Silica Composite Microspheres: Synthesis and Biomedical Applications. Nanosci. Nanotechnol. Lett. 2017, 9, 1849-1860. [CrossRef]

176. Yang, B.; Chen, B.; He, M.; Yin, X.; Xu, C.; Hu, B. Aptamer-Based Dual-Functional Probe for Rapid and Specific Counting and Imaging of MCF-7 Cells. Anal. Chem. 2018, 90, 2355-2361. [CrossRef] [PubMed]

177. Nie, L.; Liu, F.; Ma, P.; Xiao, X. Applications of gold nanoparticles in optical biosensors. J. Biomed. Nanotechnol. 2014, 10, 2700-2721. [CrossRef] [PubMed]

178. Yang, T.; Jia, H.; Liu, Z.; Qiu, X.; Gao, Y.; Xu, J.; Lu, L.; Yu, Y. Label-free electrochemical immunoassay for $\alpha$-fetoprotein based on a redox matrix of Prussian blue-reduced graphene oxide/gold nanoparticles-poly(3,4-ethylenedioxythiophene) composite. J. Electroanal. Chem. 2017, 799, 625-633. [CrossRef]

179. Nie, L.; Chen, Z.; Zou, H.; Chang, H. Development of flowing automatic quartz crystal microbalance system for DNA detection. J. Nanosci. Nanotechnol. 2013, 13, 2077-2080. [CrossRef] [PubMed]

180. Yang, M.; Li, P.H.; Xu, W.H.; Wei, Y.; Li, L.N.; Huang, Y.Y.; Sun, Y.F.; Chen, X.; Liu, J.H.; Huang, X.J. Reliable electrochemical sensing arsenic(III) in nearly groundwater $\mathrm{pH}$ based on efficient adsorption and excellent electrocatalytic ability of AuNPs $/ \mathrm{CeO}_{2}-\mathrm{ZrO}_{2}$ nanocomposite. Sens. Actuators B Chem. 2018, 255, $226-234$. [CrossRef]

181. Wang, H.; Ma, Z. A cascade reaction signal-amplified amperometric immunosensor platform for ultrasensitive detection of tumour marker. Sens. Actuators B Chem. 2018, 254, 642-647. [CrossRef] 
182. Tian, L.; Qian, K.; Qi, J.; Liu, Q.; Yao, C.; Song, W.; Wang, Y. Gold nanoparticles superlattices assembly for electrochemical biosensor detection of microRNA-21. ACS. Appl. Mater. Interfaces 2018, 99, 564-570. [CrossRef] [PubMed]

183. Nie, L.; Liu, F.; Yang, H. Preparation of Quantum Dot Fluorescence Encoded Polystyrene Microbeads. Nanosci. Nanotechnol. Lett. 2017, 9, 941-944. [CrossRef]

184. Su, S.; Sun, H.; Cao, W.; Chao, J.; Peng, H.; Zuo, X.; Yuwen, L.H.; Wang, L. Dual-target electrochemical biosensing based on DNA structural switching on gold nanoparticle-decorated $\mathrm{MoS}_{2}$ nanosheets. ACS. Appl. Mater. Interfaces 2016, 8, 6826-6833. [CrossRef] [PubMed]

185. Nie, L.; Xiao, X.; Yang, H. Preparation and Biomedical Applications of Gold Nanocluster. J. Nanosci. Nanotechnol. 2016, 16, 8164-8175. [CrossRef]

186. Xiao, X.Y.; Yang, H.C.; Jiang, P.F.; Chen, Z.; Ji, C.Y.; Nie, L.B. Multi-Functional $\mathrm{Fe}_{3} \mathrm{O}_{4} @ \mathrm{mSiO}_{2}-\mathrm{AuNCs}$ Composite Nanoparticles Used as Drug Delivery System. J. Biomed. Nanotechnol. 2017, 13, 1292-1299. [CrossRef]

187. Maciejewska-Prończuk, J.; Morga, M.; Adamczyk, Z.; Oćwieja, M.; Zimowska, M. Homogeneous gold nanoparticle monolayers-QCM and electrokinetic characteristics. Colloid Surf. A 2017, 514, 226-235. [CrossRef]

(C) 2018 by the authors. Licensee MDPI, Basel, Switzerland. This article is an open access article distributed under the terms and conditions of the Creative Commons Attribution (CC BY) license (http://creativecommons.org/licenses/by/4.0/). 